\title{
Review \\ CRISPR/Cas13-Based Platforms for a Potential Next-Generation Diagnosis of Colorectal Cancer through Exosomes Micro-RNA Detection: A Review
}

\author{
Benjamín Durán-Vinet ${ }^{1,2}{ }^{D}$, Karla Araya-Castro ${ }^{1,3}{ }^{(D)}$, Juan Calderón ${ }^{4}\left(\mathbb{D}\right.$, Luis Vergara ${ }^{2,5}$, Helga Weber ${ }^{1,2}$, \\ Javier Retamales ${ }^{6}\left(\mathbb{D}\right.$, Paulina Araya-Castro ${ }^{7}$ and Pamela Leal-Rojas ${ }^{1,2,8, *}$
}

1 Scientific and Technological Bioresource Nucleus (BIOREN-UFRO), Universidad de La Frontera, Temuco 4780000, Chile; b.duran01@ufromail.cl (B.D.-V.); karla.araya@ufrontera.cl (K.A.-C.); helga.weber@ufrontera.cl (H.W.)

2 Center of Excellence in Translational Medicine (CEMT), Biomedicine and Translational Research Laboratory, Universidad de La Frontera, Temuco 4780000, Chile; 1.vergara03@ufromail.cl

3 Innovation and Entrepreneurship Institute (iDEAUFRO), Universidad de La Frontera, Temuco 4780000, Chile

4 Center for Genetics and Genomics, School of Medicine, Institute of Science and Innovation in Medicine (ICIM), Clínica Alemana, Universidad del Desarrollo, Santiago 8320000, Chile; juancalderon@udd.cl

5 Doctoral Program in Cell and Applied Molecular Biology, Universidad de La Frontera, Temuco 4780000, Chile

6 Chilean Cooperative Group for Oncologic Research (GOCCHI), Santiago 8320000, Chile; Jretamales@gocchi.org

Citation: Durán-Vinet, B.; Araya-Castro, K.; Calderón, J.; Vergara, L.; Weber, H.; Retamales, J.; Araya-Castro, P.; Leal-Rojas, P. CRISPR/Cas13-Based Platforms for a Potential Next-Generation Diagnosis of Colorectal Cancer through Exosomes Micro-RNA Detection: A Review. Cancers 2021, 13, 4640. https://doi.org/10.3390/ cancers 13184640

Academic Editor: John Souglakos

Received: 29 July 2021

Accepted: 9 September 2021

Published: 16 September 2021

Publisher's Note: MDPI stays neutral with regard to jurisdictional claims in published maps and institutional affiliations.

Copyright: (c) 2021 by the authors. Licensee MDPI, Basel, Switzerland. This article is an open access article distributed under the terms and conditions of the Creative Commons Attribution (CC BY) license (https:/ / creativecommons.org/licenses/by/ $4.0 /)$.
7 School of Medicine, Clínica Alemana, Universidad del Desarrollo, Santiago 8320000, Chile; paulinaaraya@udd.cl

8 Department of Agricultural Sciences and Natural Resources, Faculty of Agricultural and Forestry Science, Universidad de La Frontera, Temuco 4780000, Chile

* Correspondence: pamela.leal@ufrontera.cl

Simple Summary: Colorectal cancer is one of the most prevalent cancers, whereas a significant number of cases are diagnosed in late cancer stages, and survival rates drop dramatically. MicroRNAs (miRNAs) from cancer-derived exosomes have shown promising diagnosis potential. Our review aims to present CRISPR/Cas-based molecular platforms as an inexpensive, swift, and robust detection tool of cancer-derived exosome micro-RNAs to streamline future applications based on the novel CRISPR/Cas-based platforms to achieve early CRC diagnosis.

Abstract: Colorectal cancer (CRC) is the third most prevalent cancer with the second highest mortality rate worldwide. CRC is a heterogenous disease with multiple risk factors associated, including obesity, smoking, and use of alcohol. Of total CRC cases, $60 \%$ are diagnosed in late stages, where survival can drop to about $10 \%$. CRC screening programs are based primarily on colonoscopy, yet this approach is invasive and has low patient adherence. Therefore, there is a strong incentive for developing molecular-based methods that are minimally invasive and have higher patient adherence. Recent reports have highlighted the importance of extracellular vesicles (EVs), specifically exosomes, as intercellular communication vehicles with a broad cargo, including micro-RNAs (miRNAs). These have been syndicated as robust candidates for diagnosis, primarily for their known activities in cancer cells, including immunoevasion, tumor progression, and angiogenesis, whereas miRNAs are dysregulated by cancer cells and delivered by cancer-derived exosomes (CEx). Quantitative polymerase chain reaction (qPCR) has shown good results detecting specific cancerderived exosome micro-RNAs (CEx-miRNAs) associated with CRC, but qPCR also has several challenges, including portability and sensitivity/specificity issues regarding experiment design and sample quality. CRISPR/Cas-based platforms have been presented as cost-effective, ultrasensitive, specific, and robust clinical detection tools in the presence of potential inhibitors and capable of delivering quantitative and qualitative real-time data for enhanced decision-making to healthcare teams. Thereby, CRISPR/Cas13-based technologies have become a potential strategy for early CRC diagnosis detecting CEx-miRNAs. Moreover, CRISPR/Cas13-based platforms' ease of use, scalability, and portability also showcase them as a potential point-of-care (POC) technology for CRC early diagnosis. This study presents two potential CRISPR/Cas13-based methodologies with a proposed 
panel consisting of four CEx-miRNAs, including miR-126, miR-1290, miR-23a, and miR-940, to streamline novel applications which may deliver a potential early diagnosis and prognosis of CRC.

Keywords: CRC; miRNA; exosomes; CRISPR/Cas systems; molecular diagnosis

\section{Introduction}

Colorectal cancer (CRC) has gained significant relevance during the last five years due to its increasing incidence and mortality. The International Agency for Research on Cancer and World Health Organization referred to CRC as the third most prevalent cancer with the second highest mortality rate worldwide, respectively [1,2]. Furthermore, in 2018, there were 881,000 reported deaths linked to CRC, and new cases may increase up to nearly 2.5 million by $2035[3,4]$. CRC is a heterogeneous disease, mainly developing malignant tumors on the inner colon walls and forming polyps in the rectum. In concordance with the severity of the disease, abnormal growths in the colon can be benign, non-cancerous or malignant [5]. CRC can become malignant over time when a polyp grows out of the inner wall of the colon and rectum, leading to a significant metastasis primarily affecting the liver and, less often, the lungs, bones, spinal cord, and brain [6].

CRC development is associated with several individual conditions, including age, environmental toxin exposure, genetics, alcohol consumption, and diet type. However, the exact mechanisms that trigger CRC are yet unknown [7]. CRC is usually prevented with regular screenings and exercise, while therapeutic regimen measures are comprised of surgery, chemotherapy, and radiation therapy [2]. Unfortunately, there are two significant issues with treatment procedures: (1) all CRC treatment protocols are heavily linked to severe patient toxicities and non-compliance [8], and (2) some cancer cells have shown significant resistance to most widely used treatment procedures such as chemotherapy [9]. Moreover, even with increasing efforts of early screening programs, a significant amount of CRC cases are diagnosed at an advanced CRC stage, often metastases, resulting in patient death [9].

Molecular methods based on cell-free cancer-derived extracellular vesicles, including cancer-derived exosomes micro-RNAs (CEx-miRNAs) which are circulating in the blood, have taken relevance for CRC monitoring and early diagnosis [10-12]. miRNAs are naturally stable, actively released and have shown good discerning ability with $76 \%$ sensitivity and $76 \%$ specificity [13] with numerous potential candidates such as miR-21, miR-23a, miR-1246, and miR-92a [14-16]. CEx-miRNAs profiles are primarily evaluated through reverse transcription-quantitative polymerase chain reaction (RT-qPCR) [11,15-18]. However, RT-qPCR has specific challenges, including the limit of detection and limited throughput, consistency, response-time, and portability $[19,20]$, which may affect reported sensitivity, specificity, and turnaround times, ultimately making clinical care decision-making difficult.

In the last four years, several clinical reports have presented CRISPR/Cas (clustered regularly interspaced short palindromic repeats/CRISPR-associated proteins) as a novel nucleic acids detection method [21-32]. Several studies harness these natural molecular beacon features with ssDNA/ssRNA-based fluorescent-quencher reporters (FQR) to establish ultrasensitive, inexpensive, multiplexed, and swift molecular detection platforms $[21,22,25,31]$. Thus, showcasing promising tools for worldwide early diagnosis efforts for CRC.

This review presents the potential of CRISPR/Cas-based platforms that represent a significant opportunity for next-generation, early point-of-care (POC) detection of CRC via detecting its CEx-miRNAs. To achieve this, we briefly summarize CRC relevance, current CRC diagnosis tools, their challenges, and current clinical CRC biomarkers. Therein, we revise extracellular vesicles and their cargo importance, focusing on their miRNAs and diagnosis significance to ultimately engage over CRISPR/Cas systems and their reported 
diagnosis platforms to propose potential methodologies that may streamline future CRISPR clinical applications for CRC early diagnosis.

\section{CRC Relevance, Risk Factors, and Key Stages for Diagnostic Survival}

Recent reports on CRC have highlighted that among all cancer cases, $10 \%$ correspond to CRC [33], while other reports have denominated CRC "an epidemic" [34]. Moreover, within this $10 \%$ of CRC incidence for both sexes $(1,931,590$ cases from a total of 19,292,789 cases), CRC mortality reached about half for both sexes (48.4\%, 935,173 deaths) with respect to its incidence. In contrast, more than $90 \%$ of reported total CRC mortality is concentrated in the group of 50-85+ year olds $(869,221$ deaths, see Figure 1) [35], hence highlighting the current need to further increase early diagnosis efforts by deploying novel, cost-effective methods.

A $\quad$ CRC incidence (all ages)

Other cancers incidence (all ages)

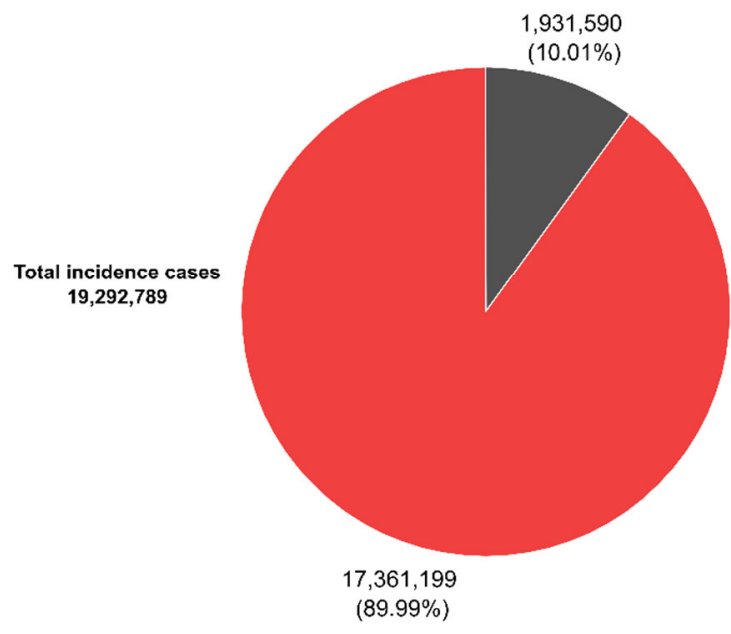

B CRC incidence (all ages, mortality subtracted) CRC mortality (all ages)

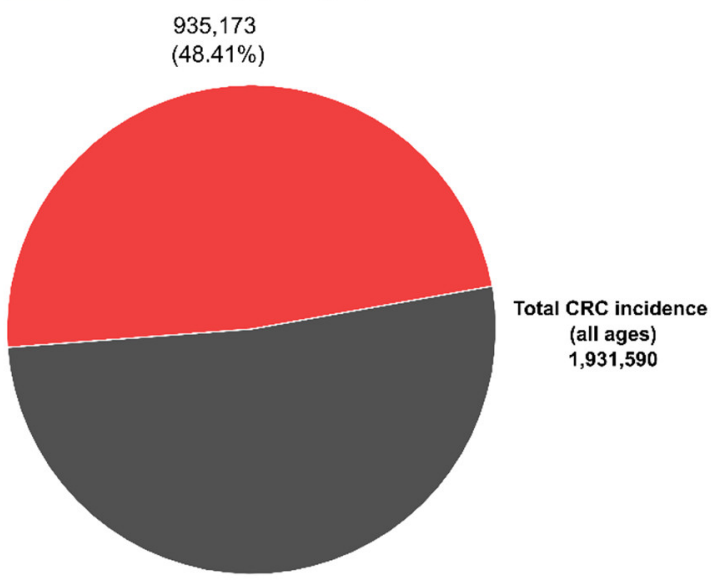

996,417

(51.59\%)

\section{CRC mortality (all ages, mortality $50+$ years old subtracted)}

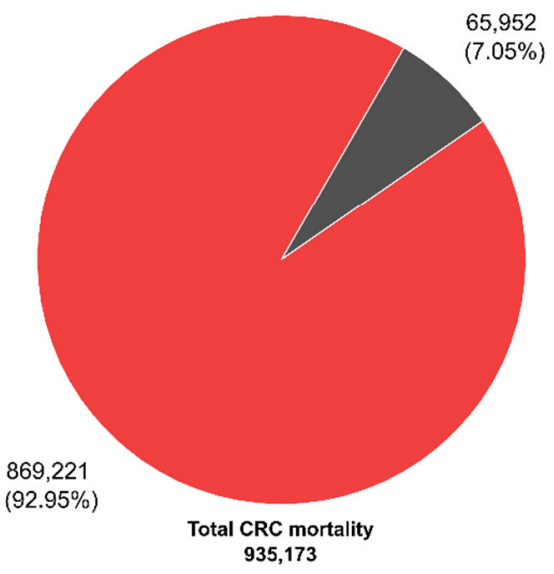

Figure 1. CRC worldwide representative statistics. (A) CRC incidence (all ages) vs. other cancer types incidences (all ages). (B) CRC incidence (all ages, mortality subtracted) vs. CRC mortality (all ages). (C) CRC mortality (all ages, mortality $50+$ years old subtracted) vs. CRC mortality (50+ years old). Data are available at [35]. 
Like other diseases, CRC formation is due to multifactorial events comprising two main components contributing to CRC development: genetic, DNA methylation alterations, and environmental elements [36]. Genetic-based studies have estimated CRC heritability to be around only $35-40 \%[33,37,38]$, showcasing a significant environmental in-fluence on CRC formation and development. Accordingly, considerable data aim for different environmental risk sources, including gut microbiota [33], dietary patterns, obesity, and smoking (further reading can be found in in-depth reviews [39]).

Currently, CRC is represented by five subtypes: adenocarcinomas (representing over $90 \%$ of CRCs diagnoses), carcinoid tumors, gastrointestinal stromal tumors, lymphomas, and sarcomas [33,40]. Clinically, CRC staging is based on three criteria: (1) cancer level of expansion in the intestine wall, (2) affection of other nearby structures, and (3) lymph nodes or distant organs being reached. These are described by the American Joint Committee on Cancer (AJCC) [41]. In brief, AJCC classifies cancer in four stages: (0) abnormal cells present that may lead to cancer, (I) cancer cells present but only locally spread not affecting other nearby tissue, (II) cancer cells present and affecting nearby tissue, (III) cancer cells have reached lymph nodes and, (IV) cancer cells have reached distant parts of the body. Moreover, cancer can also be classified using the TNM staging system, whereas T refers to the primary tumor size which has not yet reached lymph nodes (equivalent to stages I and II of the AJCC), $\mathrm{N}$ describes cancer cells that have reached one or more lymph nodes (equivalent to stage III of the AJCC), and M describes whether the cancer has metastasized, i.e., the primary tumor has reached other parts of the body (equivalent to stage IV of the AJCC) [41-43].

CRC, its stages, short/long-term survivability, and prognosis predictions have been primarily studied and reviewed elsewhere [44-47]. Furthermore, reports have high-lighted the sudden decrease of five-year survival rates as TNM or AJCC staging increases [41,48], whereas from $\mathrm{T}$ to $\mathrm{N}$, the survival rate decreases by almost $20 \%$, from $90.6 \%$ to $72.2 \%$, respectively, and from $\mathrm{N}$ to $\mathrm{M}$ dramatically drops practically $60 \%$, from $72.2 \%$ to $14.7 \%$, respectively [43]. Hence, there is a considerable number of initiatives to obtain reliable and specific tools and biomarkers to establish an early diagnosis of CRC [49]; however, early CRC diagnosis is still a challenge since only $40 \%$ of CRC cases are diagnosed at stage I [50] either due to lack of compliance or test-related issues (e.g., sensitivity, specificity, false positives and negatives) from current routine procedures including colonoscopy, fecal immunochemical test (FIT), and guaiac-based fecal occult blood test (gFOBT) [13,51,52]. Thereby, molecular diagnosis has risen as a swift and affordable route to obtain an early CRC diagnosis [53], to be followed by suitable treatments, including chemotherapy [54], radiotherapy [55], immunotherapy [56], targeted therapy [57], and other therapies (further reading can be found in $[9,58,59])$, thus ultimately preventing, to some extent, patients' deaths and life-quality deterioration.

\section{Current CRC Diagnosis and Their Challenges: Traditional and Molecular Methods}

In terms of diagnosis, survival rates rely directly on the CRC stage at the time of diagnosis; thereby, CRC can be a preventable and treatable disease with current CRC treatments if an early diagnosis is provided $[60,61]$, considerably enhancing medical outcomes with a five-year survival rate to $90 \%$ in cases diagnosed early [62]. Moreover, in contrast with other types of cancer, CRC develops and progresses slowly over the years; it can be up to decades before normal colorectal epithelium transform into an adenoma [34,63]. However, despite systematic public awareness campaigns on CRC and early diagnosis efforts, $50 \%$ of CRC-diagnosed patients already carry metastasis [64].

Late CRC diagnoses may be explained by numerous factors playing pivotal roles for diagnosis, including that CRC is comprised of a heterogeneous cancer population, known as consensus molecular subtypes of cancer (CSM1 to 4; further in-depth reading in $[64,65]$ ). CSM1 to 4 merges up to 27 CRC subtypes, representing four groups with different gene expression profiles between different regions of the tumor and tumor microenvironment (TME) components [66]. Moreover, intra-tumor heterogenicity (ITH) also drives to spatial 
heterogenicity [67], where CRC fully differentiates into functional cells and immature cancer stem cells inside the same cancer $[67,68]$. Thus, from a molecular point of view, ITH directly impacts heterogeneous sensitivity to current, established CRC treatments and their prognosis $[69,70]$; therefore, early molecular diagnosis efforts may also be affected by CRC ITH, further complicating current early diagnosis efforts.

Established traditional and routinary diagnostic tools have shown good overall efficacy in diagnosis, thus decreasing CRC-related mortality (see Table 1). However, several factors can affect traditional methods and their effectiveness, including low efficacy, high costs, lack of accessibility, limitations of test performance, invasiveness, and suboptimal screening compliance [11,71]. Instead, molecular methods, for which detection is based on either specific segment DNA or RNA obtained from significantly less invasive sampling (e.g., blood samples), have proven to be practical tools, with significant efficacy, lower costs, and faster turnarounds (see Table 1) [20,36,72].

Table 1. Current traditional clinical methods and molecular methods for CRC diagnosis.

\begin{tabular}{|c|c|c|c|c|c|}
\hline Methods & Cost & $\underset{*}{\text { Time }}$ & Advantages & Disadvantages & References \\
\hline \multicolumn{6}{|l|}{ Traditional methods } \\
\hline $\begin{array}{l}\text { Guaiac-based fecal } \\
\text { occult blood test } \\
\text { (gFOBT) }\end{array}$ & Low & Weeks & $\begin{array}{l}\text { Biennial gFOBT screening } \\
\text { provides sustained protection } \\
\text { against long-term CRC mortality }\end{array}$ & $\begin{array}{l}\text { Unspecific, limited sensitivity for } \\
\text { CRC detection, requires patient } \\
\text { dietary modification and three } \\
\text { consecutive samples are needed. }\end{array}$ & [73-76] \\
\hline $\begin{array}{l}\text { Fecal } \\
\text { immunochemical } \\
\text { test }(\mathrm{FIT})\end{array}$ & Low & Weeks & $\begin{array}{l}\text { Quantitative and qualitative } \\
\text { results, user-friendly application, } \\
\text { higher overall adherence and } \\
\text { easier follow-up. }\end{array}$ & $\begin{array}{c}\text { Test reliability decreases } \\
\text { considerably with longer times } \\
\text { before analysis. }\end{array}$ & [74-76] \\
\hline $\begin{array}{l}\text { Multi-target stool } \\
\text { DNA test }\end{array}$ & High & Weeks & $\begin{array}{l}\text { High sensitivity, non-invasive } \\
\text { approach, and good benefit-risk } \\
\text { ratios }\end{array}$ & $\begin{array}{l}\text { Sensitivity is partially linked to } \\
\text { hemoglobin thresholds and } \\
\text { showcases a lower rate of cancer } \\
\text { prevention }\end{array}$ & {$[75,77]$} \\
\hline Colonoscopy & High & Hours & $\begin{array}{l}\text { High efficacy and sensitivity on } \\
\text { preventing CRC due to detecting } \\
\text { and removing both advanced and } \\
\text { non-advanced adenomas. }\end{array}$ & $\begin{array}{l}\text { Invasive, need sedation and } \\
\text { bowel cleansing. High risks } \\
\text { linked to human manipulation } \\
\text { errors including perforation, } \\
\text { bleeding, and death. }\end{array}$ & {$[75,77]$} \\
\hline $\begin{array}{l}\text { CT colonography } \\
\text { (virtual colonoscopy) }\end{array}$ & High & Hours & $\begin{array}{l}\text { Non-invasive and effective } \\
\text { screening test with low risk of } \\
\text { perforation }\end{array}$ & $\begin{array}{l}\text { Bowel preparation and lower } \\
\text { sensitivity in comparison with } \\
\text { colonoscopy. }\end{array}$ & {$[75,77]$} \\
\hline \multicolumn{6}{|l|}{ Molecular methods } \\
\hline qPCR & Low & Days & $\begin{array}{l}\text { Minimally invasive, fast, and } \\
\text { accurate detection. The process } \\
\text { has been automated. }\end{array}$ & $\begin{array}{l}\text { Multi-target approaches and } \\
\text { fluorescent reporters-related } \\
\text { applicability is variable, affecting } \\
\text { sensitivity and specificity. }\end{array}$ & {$[78,79]$} \\
\hline RT-qPCR & Low & Days & $\begin{array}{l}\text { Minimally invasive and accurate } \\
\text { detection. Currently } \\
\text { gold-standard method. }\end{array}$ & $\begin{array}{l}\text { Error-prone and reliability } \\
\text { directly linked to sample } \\
\text { extraction quality from clinical } \\
\text { samples. Labor-intensive. Low } \\
\text { portability. }\end{array}$ & {$[78,80]$} \\
\hline
\end{tabular}


Table 1. Cont

\begin{tabular}{|c|c|c|c|c|c|}
\hline Methods & Cost & $\underset{*}{\text { Time }}$ & Advantages & Disadvantages & References \\
\hline ddPCR & Low & Days & $\begin{array}{l}\text { Minimally invasive with } \\
\text { improved analytical sensitivity to } \\
\text { mutations such as KRAS. } \\
\text { Reduced variability. }\end{array}$ & $\begin{array}{l}\text { Trained personnel, } \\
\text { labor-intensive, and high rates of } \\
\text { false positives. }\end{array}$ & {$[81,82]$} \\
\hline Microarrays & Medium & $\begin{array}{l}\text { Days- } \\
\text { Weeks }\end{array}$ & $\begin{array}{l}\text { Minimally invasive with high } \\
\text { sensitivity to analyze multiple } \\
\text { targets from one sample. }\end{array}$ & $\begin{array}{l}\text { Time and laborious technical } \\
\text { procedures, along with multiple } \\
\text { runs needed to obtain final } \\
\text { results. }\end{array}$ & [83] \\
\hline $\begin{array}{l}\text { Next-generation } \\
\text { sequencing }\end{array}$ & High & Weeks & $\begin{array}{l}\text { A broader assessment of the } \\
\text { tumor molecular profile, } \\
\text { including mutations and ITH } \\
\text { dynamics. }\end{array}$ & $\begin{array}{l}\text { Resource-consuming and efficacy } \\
\text { may be affected by numerous } \\
\text { factors }\end{array}$ & [84] \\
\hline $\begin{array}{l}\text { CRISPR/Cas } \\
\text { platforms }\end{array}$ & $\begin{array}{l}\text { Very } \\
\text { low }\end{array}$ & $\begin{array}{l}\text { Hours- } \\
\text { Days }\end{array}$ & $\begin{array}{c}\text { Minimally invasive detection } \\
\text { with swift, cost-effective, } \\
\text { ultrasensitive, and specific } \\
\text { platforms. }\end{array}$ & $\begin{array}{l}\text { Detailed sequence data needed, } \\
\text { sensitive to unidentified } \\
\text { mutations and RNA secondary } \\
\text { structures. }\end{array}$ & {$[22,24,85]$} \\
\hline
\end{tabular}

Further in-detail reading about molecular methods for CRC diagnosis can be found in [20]. * Expressed times are referential to a delivered clinical result to the patient.

Furthermore, although molecular diagnostic methods have significantly improved CRC screening, similarly to traditional diagnostics, these also carry limitations and challenges. The gold standard technique currently in use, qPCR and RT-qPCR, has been reported to have several restraints $[19,20,86,87]$. Thus, CRISPR/Cas-based diagnosis (CRISPR-Dx) technologies may represent a potential opportunity to further improve current molecular diagnosis efforts due to their ultrasensitive and robust bio-sensing properties, especially when there have been significant advances in CRISPR-Dx technologies in clinical research and clinical applications [88].

\section{Current Clinical Molecular Biomarkers for CRC}

Molecular methods base their detection on molecular biomarkers, defined as specific and characteristic DNA or RNA segments with high value for diagnostic and prognosis assessments, whether because they are mechanistically implied with the phenotype of interest or rather just correlated to it. There have been multiple efforts to characterize novel and reliable molecular biomarkers for CRC associated with heterogeneity and clinical stages (see Table 2).

Although current molecular biomarkers have a good performance, these perform correctly only within a small population of patients at specific CRC stages and with specific molecular characteristics, rendering them insufficient for a wide-range CRC diagnosis [20,94]. Thus, the research community keeps moving forward to develop new and more accessible molecular biomarkers that can be found more abundantly and with a broader diagnosis range, capable of diagnosing most CRC stages despite its heterogeneity, since CRC early diagnosis is critical for survival and is currently in high demand $[95,96]$.

Interestingly, recent reports indicate that some CRC-related bacteria are related to early and late CRC stages, showcasing bacteria as potential CRC molecular biomarkers for early diagnosis [97]. There are also reports showcasing cancer-derived exosomes miRNAs (CEx-miRNAs) and circular RNA (circRNA) as potential biomarkers for CRC diagnosis and prognosis [98-101].

Current traditional and molecular methods clinically used for CRC diagnosis require specialized technical expertise and equipment, highlighting the necessity for developing more straightforward, robust, cost-effective diagnosis platforms for broader, bigger, and more accessible use (further revision can be found in $[20,96,102,103])$. In keeping with this 
premise, CEx-miRNAs alongside CRISPR/Cas-based platforms may represent a potential candidate to solve these issues, either via POC platforms or clinical-based tests.

Table 2. Most used CRC molecular biomarkers clinically used for diagnosis and prognosis.

\begin{tabular}{|c|c|c|c|c|}
\hline $\begin{array}{l}\text { Molecular } \\
\text { Biomarkers }\end{array}$ & Sample Type ${ }^{a}$ & Example Target & $\begin{array}{c}\text { Overall } \\
\text { Effectiveness } \\
\text { (SE/SP) }\end{array}$ & References \\
\hline $\begin{array}{l}\text { Adenomatous } \\
\text { polyposis coli } \\
\text { (APC) }\end{array}$ & $\begin{array}{l}\text { Blood } \\
\text { (DNA) }\end{array}$ & $\begin{array}{c}\text { D18122V, } \\
\text { E1317Q, and } \\
\text { I1307K (APC } \\
\text { polymorphisms) }\end{array}$ & NR * & [89] \\
\hline $\begin{array}{c}\text { Microsatellite } \\
\text { instability (MSI) }\end{array}$ & $\begin{array}{l}\text { Blood } \\
\text { (DNA) }\end{array}$ & Bat-25, NR-21 & $\begin{array}{c}99 \% \\
(98.7 / 100)\end{array}$ & [90] \\
\hline $\begin{array}{l}\text { Methylation } \\
\text { (MTL) }\end{array}$ & $\begin{array}{l}\text { Blood/Stool } \\
\text { (DNA) }\end{array}$ & SEPT9 & $\begin{array}{c}89 \% \\
(90 / 88)\end{array}$ & [91] \\
\hline $\begin{array}{c}\text { Kirsten rat } \\
\text { sarcoma viral } \\
\text { oncogene } \\
\text { homolog (KRAS) }\end{array}$ & $\begin{array}{l}\text { Blood } \\
\text { (DNA) }\end{array}$ & $\begin{array}{l}\text { p-21Ras } \\
\text { mutations }\end{array}$ & $\begin{array}{c}60 \% \\
(67 / 53.95)\end{array}$ & [92] \\
\hline $\begin{array}{l}\text { V-raf murine } \\
\text { sarcoma vViral } \\
\text { oncogene } \\
\text { homolog B1 } \\
\text { (BRAF) }\end{array}$ & $\begin{array}{l}\text { Blood } \\
\text { (DNA) }\end{array}$ & $\begin{array}{c}\text { BRAF V600 E } \\
\text { mutation }\end{array}$ & $\begin{array}{c}77 \% \\
(81.2 / 72.1)\end{array}$ & [93] \\
\hline
\end{tabular}

\section{Extracellular Vesicles as Potential Molecular Biomarkers for Early Diagnosis}

Among the numerous biomarkers reported to date, extracellular vesicles (EVs) have been given particular attention by the research community. EVs comprise three vesicle types, including apoptotic bodies, exosomes, and microvesicles (see Figure 2 [104]); they are secreted and released by almost all cells, including cancerous cells.

\section{Extracellular vesicles}

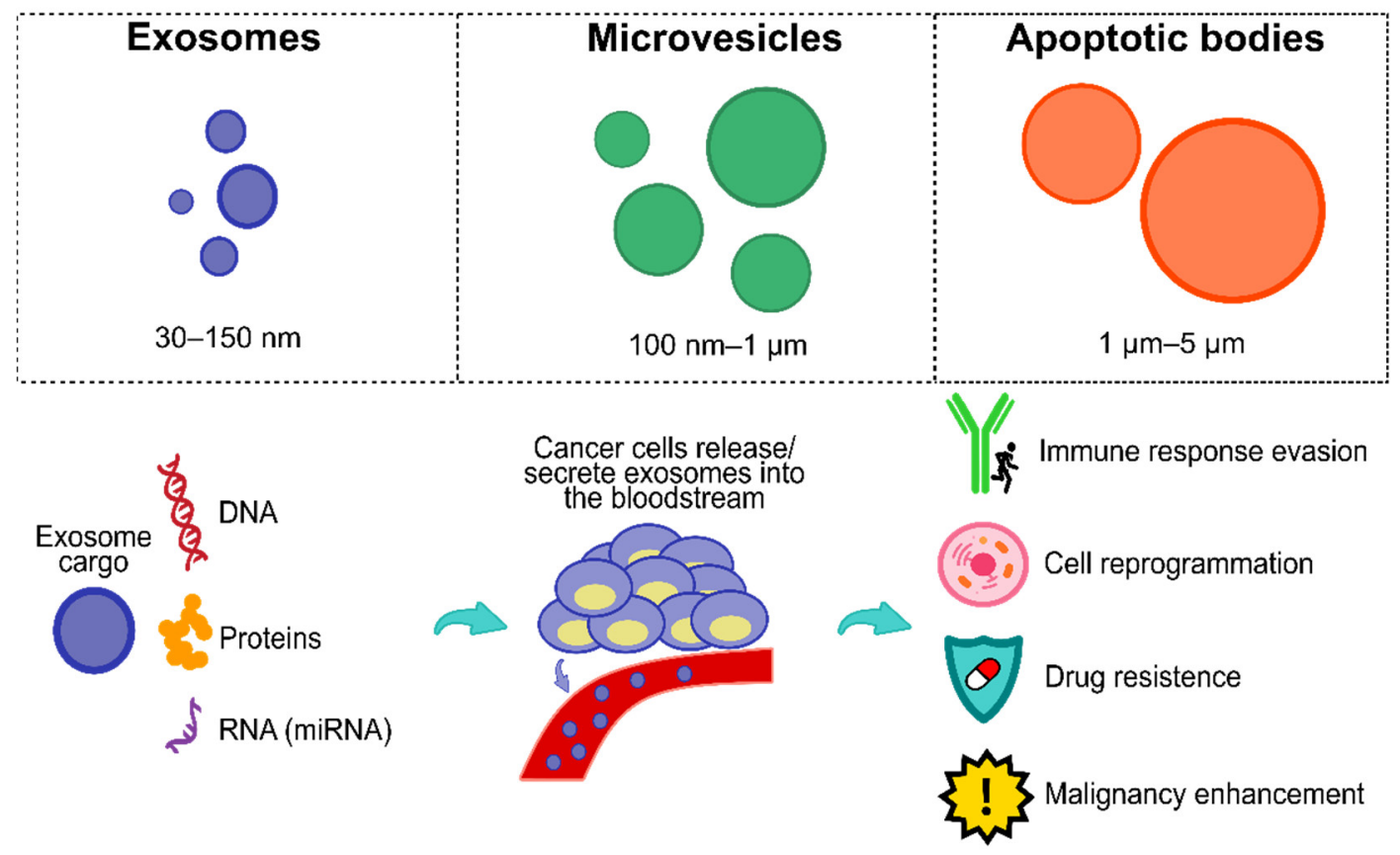

Figure 2. EVs and the importance of exosomes. Exosomes have a plethora of cargo (e.g., proteins, DNA, RNA, micro RNAs, among others). Cancer cells hijack exosomes and their cargo, releasing/secreting them into the bloodstream to obtain several features, including immune response evasion, cell reprogramming, drug resistance, and malignancy enhancement. 
EVs are physiologically essential since they play a role in two significant functions: (1) cellular waste management and (2) intercellular communication, i.e., EVs are highly stable and efficient cellular communication vehicles with significant cargos including proteins, lipids, metabolites, and nucleic acids (DNA, messenger RNAs, miRNAs, and long non-coding RNAs), with the ultimate purpose of cargo transfer to mediate intercellular physiological and pathological conditions, inducing homeostatic changes on target cells. Structurally, EVs are comprised of a circular phospholipid bi-layer and are unable to divide. This structure is essential because it confers significant stability, resistance to degradation, and longer half-life to its cargo, endowing EVs with an ideal and versatile intercell communication vehicle. Moreover, EVs' structure allows its cargo to be efficiently delivered into the target cells [105-107].

Interestingly, cancer cells hijack and exploit EVs' signalling network for their bene-fit (see Figure 2), including cell reprogramming towards tumor-promoting intra- and intercellular environments, stimulating cancer development and enhancing survival, angiogenesis, invasion, and metastasis through cargos that support nearby cancer cells to evade immune responses and cell death during all cancer stages [104], which may confer superior diagnostic and prognostic features in comparison to other circulating biomarker types due to their relative abundance, stability, and the array of targets they express [104,105]. It is essential to mention that currently there is no clear consensus on the current release amount of EVs, i.e., studies highlight that cancer cells release significantly more EVs than normal cells, whereas other studies show no significant difference [106]. This issue may be explained due to the lack of standardized protocols and consensus about optimal EV extraction, isolation, and purification from clinical or cell culture samples [106,107]. However, a review study from Choudhry et al. [108] showed how tumor cells significantly increase EV production and release, specifically cancer-derived exosomes (CEx), to induce themselves and nearby cells into hypoxia to enhance the release of higher amounts of CEx, thereby also reaching distant cells to induce hypoxia and ultimately promoting cancer progression. Accordingly, recent reports have also had similar results about the larger amount of CEx released by tumor cells than by normal cells [109-111].

Moreover, they play specific roles in CRC malignant progression and responses to therapies [112,113], hence also carrying several potential diagnostical molecules (an in-depth review of EV types, biogenesis, and cargos can be found in [114-117]). CEx have been shown to alter the origin of the tumor microenvironment and their functional cargo to modulate and support oncogenic mechanisms including angiogenesis, immune modulation, and metastasis, enhancing cancer malignancy features [118-120], including chemotherapy and drug resistance (an in-depth review of the role of EVs and CEx can be found in [121]). Furthermore, CEx can be easily obtained from patient biological fluids, including blood, plasma, serum, and urine [122], therefore converting CEx and their cargo into potential biomarkers for CRC surveillance, early diagnosis, and prognosis.

Some attractive benefits from CEx-based diagnostics are (1) less invasive methods, (2) easier patient follow-up of their cancer stage, and (3) easier surveillance of patient cancer relapse; nonetheless, there are also drawbacks, including (1) CEx may be highly heterogeneous due to physiological conditions (e.g., stress), (2) time required and high cost for their analysis, and (3) methods must promise high sensitivity and specificity [16]. Accordingly, CEx-based diagnostics are promising, but several milestones need to be tackled, specially CEx isolation standardization and characterization to obtain cost-effective methods with swift turnaround times.

\section{CEx-miRNAs for CRC Diagnosis}

miRNAs are small non-coding RNAs (18-24 nucleotides) that perform post-transcriptional regulation of mRNAs, mainly playing an inhibiting role when binding to the mRNA $3^{\prime}$ untranslated region, ultimately impeding their translation or leading to degradation [123]. miRNAs regulate several biological processes, including cellular differentiation, proliferation, and apoptosis; thus, they can be easily found in blood samples and are easy to 
obtain and minimally invasive [123]. Hence, miRNA expression dysregulation can lead to various types of cancer, including CRC [124]. miRNAs are also essential for cancer progression due to reported observations that they play critical roles in regulating cancer signalling mechanisms, enhancing several factors, including tumor growth, angiogenesis, and metastasis [125].

Furthermore, Wang et al. [126] recently demonstrated that CEx-miRNA miR-NA-25 substantially facilitated CRC development and metastasis, pinpointing the importance of miRNAs not only as cancer-promoting molecules but also molecules that carry major diagnosis and prognosis potential for patients (in-depth reading about miRNAs biogenesis, pathways, and their relevance can be found in [123]).

Additionally, several studies have indicated that blood samples have emerged as a reliable source of biomarkers $[127,128]$. Accordingly, cancer-related miRNAs, either CEx-miRNAs or cancer-derived cell-free miRNAs (cf-miRNAs), from blood represents a promising target for more accessible and non-invasive testing $[129,130]$. In this regard, blood CEx and miRNA extraction can be easily achieved through available commercial kits, delivering precise and valuable diagnostic and prognostic data [131-133].

CRC-related miRNAs can be found in blood in two variations: (1) cf-miRNA and (2) CEx-miRNAs. However, CEx-miRNAs are selectively released by tumour cells, enhancing miRNA specificity and stability compared with cf-miRNAs, which are more vulnerable to degradation [134]. Hence, several studies suggest CEx-miRNAs as a better, easier to obtain, robust, and reliable alternative as a molecular biomarker for cancer diagnosis and prognosis, including CRC $[132,135,136]$. Accordingly, there are several CEx-miRNAs related to specific CRC staging with a dual biomarker property whereby they can function as diagnosis and prognosis biomarkers (see Table 3). It is pivotal to mention that the best performance results for CRC diagnosis and prognosis are based on CEx-miRNAs panels (e.g., $[137,138])$, highlighting the importance of multitargeted-based detections to enhance early diagnoses and prognoses for CRC and other cancers.

Table 3. Summary of promising reported miRNA from patient blood samples for potential CRC diagnosis and prognosis since 2017.

\begin{tabular}{|c|c|c|c|c|c|c|c|}
\hline $\begin{array}{l}\text { miRNA (By } \\
\text { Stages) }^{a}\end{array}$ & $\begin{array}{c}\text { Qualitative } \\
\text { Regulation } b\end{array}$ & AUC & $\begin{array}{c}\text { Sequence } \\
(3 p / 5 p-\text { length-bp) }\end{array}$ & $\begin{array}{l}\text { Accession } \\
\text { Number }\end{array}$ & $\begin{array}{l}\text { Qualitative } \\
\text { Prognosis }\end{array}$ & Source & Reference \\
\hline \multicolumn{8}{|l|}{$\mathrm{T}(\mathrm{I} \& \mathrm{II})$} \\
\hline miR-126 & $\uparrow$ & 0.96 & $\begin{array}{c}\text { UCG UAC CGU GAG } \\
\text { UAA UAA UGC G (3p-22) }\end{array}$ & MI0000471 & Early CRC stage & CEx & [136] \\
\hline $\operatorname{miR}-1290$ & $\uparrow$ & 0.91 & $\begin{array}{l}\text { UGG AUU UUU GGA } \\
\text { UCA GGG A (19) }\end{array}$ & MI0006352 & Early CRC stage & CEx & [136] \\
\hline miR-186-5p & $\uparrow$ & 0.72 & $\begin{array}{l}\text { CAAA GAA UUC UCC } \\
\text { UUU UGG GCU (21) }\end{array}$ & MI0000483 & $\begin{array}{l}\text { CRC early } \\
\text { lesions }\end{array}$ & cf-miRNAs & [139] \\
\hline $\operatorname{miR}-23 a$ & $\uparrow$ & 0.92 & $\begin{array}{c}\text { AUC ACA UUG CCA } \\
\text { GGG AUU UCC }(3 \mathrm{p}-21)\end{array}$ & MI0000079 & Early CRC stage & CEx & [136] \\
\hline $\operatorname{miR}-423-5 p$ & $\downarrow$ & 0.72 & $\begin{array}{c}\text { UGA GGG GCA GAG } \\
\text { AGC GAG ACU UU (23) }\end{array}$ & MI0001445 & $\begin{array}{l}\text { CRC early } \\
\text { lesions }\end{array}$ & cf-miRNAs & [139] \\
\hline $\operatorname{miR}-449 a$ & $\downarrow$ & 0.76 & $\begin{array}{l}\text { UGG CAG UGU AUU } \\
\text { GUU AGC UGG U (22) }\end{array}$ & MI0001648 & $\begin{array}{c}\text { Poor prognosis, } \\
\text { lower overall } \\
\text { survival }\end{array}$ & cf-miRNAs & [140] \\
\hline miR-592 & $\uparrow$ & 0.80 & $\begin{array}{l}\text { UUG UGU CAA UAU } \\
\text { GCG AUG AUG U (22) }\end{array}$ & MI0003604 & Early CRC stage & cf-miRNAs & [141] \\
\hline miR-940 & $\uparrow$ & 0.90 & $\begin{array}{l}\text { AAG GCA GGG CCC } \\
\text { CCG CUC CCC (21) }\end{array}$ & MI0005762 & Early CRC stage & CEx & [136] \\
\hline
\end{tabular}


Table 3. Cont.

\begin{tabular}{|c|c|c|c|c|c|c|c|}
\hline $\begin{array}{l}\text { miRNA (By } \\
\text { Stages) }^{a}\end{array}$ & $\begin{array}{l}\text { Qualitative } \\
\text { Regulation } b\end{array}$ & AUC & $\begin{array}{c}\text { Sequence } \\
(3 p / 5 p-l e n g t h-b p)^{c}\end{array}$ & $\begin{array}{c}\text { Accession } \\
\text { Number }\end{array}$ & $\begin{array}{l}\text { Qualitative } \\
\text { Prognosis }\end{array}$ & Source & Reference \\
\hline \multicolumn{8}{|l|}{ N (III) } \\
\hline miR-1539 & $\uparrow$ & 0.67 & $\begin{array}{l}\text { UCC UGC GCG UCC } \\
\text { CAG AUG CCC (21) }\end{array}$ & MI0007260 & $\begin{array}{l}\text { CRC lymph node } \\
\text { invasion and } \\
\text { poor clinico- } \\
\text { pathological } \\
\text { behavior }\end{array}$ & CEx & [142] \\
\hline miR-19a & $\uparrow$ & 0.87 & $\begin{array}{l}\text { UGU GCA AAU CUA } \\
\text { UGC AAA ACU GA } \\
(3 p-23)\end{array}$ & MI0000073 & CRC invasion & cf-miRNAs & [143] \\
\hline miR-20a & $\uparrow$ & 0.83 & $\begin{array}{c}\text { UAA AGU GCU UAU } \\
\text { AGU GCA GGU AG } \\
(5 p-23)\end{array}$ & MI0000076 & $\begin{array}{l}\text { CRC increasing } \\
\text { distant } \\
\text { metastasis rates }\end{array}$ & cf-miRNAs & [143] \\
\hline miR-150 & $\uparrow$ & 0.75 & $\begin{array}{c}\text { UCU CCC AAC CCU } \\
\text { UGU ACC AGU G }(5 p-22)\end{array}$ & MI0000479 & $\begin{array}{l}\text { CRC promoting } \\
\text { epithelial to } \\
\text { mesenchymal } \\
\text { transition }\end{array}$ & cf-miRNAs & [143] \\
\hline miR-552 & $\uparrow$ & NR & $\begin{array}{l}\text { AAC AGG UGA CUG } \\
\text { GUU AGA CAA (3p-21) }\end{array}$ & MI0003557 & $\begin{array}{c}\text { CRC poor } \\
\text { prognosis, worse } \\
\text { 5-year overall } \\
\text { survival }\end{array}$ & cf-miRNAs & [144] \\
\hline \multicolumn{8}{|l|}{ M (IV) } \\
\hline miR-126-3p & $\uparrow$ & NR & $\begin{array}{l}\text { UCG UAC CGU GAG } \\
\text { UAA UAA UGC G (22) }\end{array}$ & MI0000471 & $\begin{array}{l}\text { *Progression- } \\
\text { free } \\
\text { survival }\end{array}$ & cf-miRNAs & [145] \\
\hline miR-155-5p & $\uparrow$ & NR & $\begin{array}{l}\text { UUA AUG CUA AUC } \\
\text { GUG AUA GGG GUU } \\
(24)\end{array}$ & MI0000681 & $\begin{array}{l}{ }^{*} \text { Short } \\
\text { progression-free } \\
\text { survival }\end{array}$ & cf-miRNAs & [146] \\
\hline $\operatorname{miR}-17-5 p$ & $\uparrow$ & 0.90 & $\begin{array}{l}\text { CAA AGU GCU UAC } \\
\text { AGU GCA GGU AG (23) }\end{array}$ & MI0000071 & $\begin{array}{l}\text { CRC increased } \\
\text { invasive ability } \\
\text { and metastasis } \\
\text { potential }\end{array}$ & CEx & [147] \\
\hline $\operatorname{miR}-19 b$ & $\uparrow$ & 0.89 & $\begin{array}{l}\text { UGU GCA AAU CCA } \\
\text { UGC AAA ACU GA (3p } \\
23)\end{array}$ & MI0000074 & $\begin{array}{l}\text { High amounts } \\
\text { indicate } \\
\text { metastatic CRC }\end{array}$ & CEx & [132] \\
\hline miR-20b-5p & $\uparrow$ & NR & $\begin{array}{l}\text { CAA AGU GCU CAU } \\
\text { AGU GCA GGU AG (23) }\end{array}$ & MI0001519 & $\begin{array}{l}\text { *Progression- } \\
\text { free } \\
\text { survival }\end{array}$ & cf-miRNAs & [146] \\
\hline $\operatorname{miR}-21$ & $\uparrow$ & 0.98 & $\begin{array}{c}\text { UAG CUU AUC AGA } \\
\text { CUG AUG UUG A (5p-22) }\end{array}$ & MI0000077 & $\begin{array}{l}\text { High amounts } \\
\text { indicate } \\
\text { metastatic CRC }\end{array}$ & CEx & [132] \\
\hline $\operatorname{miR}-222$ & $\uparrow$ & 0.90 & $\begin{array}{l}\text { AGC UAC AUC UGG } \\
\text { CUA CUG GGU }(3 p-22)\end{array}$ & MI0000299 & $\begin{array}{l}\text { Higher amounts } \\
\text { indicate a lower } \\
\text { overall survival } \\
\text { rate }\end{array}$ & CEx & [132] \\
\hline miR-29b-3p & $\uparrow$ & NR & $\begin{array}{l}\text { UAG CAC CAU UUG } \\
\text { AAA UCA GUG UU (23) }\end{array}$ & MI0000105 & $\begin{array}{l}\text { *Progression- } \\
\text { free } \\
\text { survival }\end{array}$ & cf-miRNAs & [146] \\
\hline miR-320d & $\uparrow$ & 0.63 & $\begin{array}{l}\text { AAA AGC UGG GUU } \\
\text { GAG AGG A (19) }\end{array}$ & MI0008190 & $\begin{array}{c}\text { Distinguish } \\
\text { metastatic from } \\
\text { non-metastatic } \\
\text { CRC. }\end{array}$ & CEx & [148] \\
\hline
\end{tabular}


Table 3. Cont.

\begin{tabular}{|c|c|c|c|c|c|c|c|}
\hline $\begin{array}{l}\text { miRNA (By } \\
\text { Stages) }^{a}\end{array}$ & $\begin{array}{l}\text { Qualitative } \\
\text { Regulation } b\end{array}$ & AUC & $\begin{array}{c}\text { Sequence } \\
(3 p / 5 p-\text { length-bp) }\end{array}$ & $\begin{array}{l}\text { Accession } \\
\text { Number }\end{array}$ & $\begin{array}{l}\text { Qualitative } \\
\text { Prognosis }\end{array}$ & Source & Reference \\
\hline $\operatorname{miR}-92 a$ & $\uparrow$ & 0.95 & $\begin{array}{c}\text { UAU UGC ACU UGU } \\
\text { CCC GGC CUG U (3p-22) }\end{array}$ & MI0000093 & $\begin{array}{l}\text { Higher amounts } \\
\text { indicate a higher } \\
\text { risk of tumor } \\
\text { progression }\end{array}$ & CEx & [132] \\
\hline miR-92a-3p & $\uparrow$ & 0.85 & $\begin{array}{l}\text { UAU UGC ACU UGU } \\
\text { CCC GGC CUG U (22) }\end{array}$ & MI0000093 & $\begin{array}{l}\text { CRC increased } \\
\text { invasive ability } \\
\text { and metastasis } \\
\text { potential }\end{array}$ & CEx & [147] \\
\hline
\end{tabular}

NR: not reported; $\uparrow:$ upregulated; $\downarrow$ : downregulated. ${ }^{*}$ miRNAs associated with a prognosis after treatment were delivered. ${ }^{a}$ Mentioned miRNAs are often present during all the stages of the disease, although their expression level shifts and are significant compared to healthy controls. ${ }^{b}$ In comparison with healthy controls. There can be variations depending on the CRC mutation type. ${ }^{c}$ Stem-loop sequences were not considered. Reference sequences were obtained from $[149,150]$. When $3 p / 5 p$ were not mentioned, the annotation with higher reads was used when possible. A focused review on circulating exosomal miRNA and their role in the diagnosis, prognosis, surveillance, and monitoring of CRC can be found in [138].

Moreover, there are also several miRNAs linked to poor performance on early diagnosis [151], highlighting a current need to characterize CEx-miRNAs and cf-miRNAs further since overall miRNA expression can be altered by several situations, including ITH, treatments, and patient metabolism stresses $[145,152]$. Thus, further research is needed to simultaneously screen higher numbers of miRNAs candidates to study their fluctuation under different conditions to understand miRNA dysregulation patterns in patients, ultimately enhancing patient diagnosis and prognosis. Accordingly, there is also a need for current and future CRC miRNA biomarkers reports to be in-depth and characterized to be able to discern TNM staging, progression, and their predictive performance (e.g., area under the curve; AUC) as a minimum report standard for a comparable, comprehensive, and accurate diagnosis for CRC and other cancers to achieve swift early diagnostics.

A blood-based miRNA diagnostic for cancers is currently trending and being intensely studied $[127,136,153,154]$. Therefore, the current challenges previously mentioned may soon be addressed and tackled. Moreover, recent reports have aimed to use saliva as a source of cancer-derived miRNAs, obtaining promising results for CRC $[155,156]$. The use of blood and saliva as a source of biomarkers may help close the gap to achieve reliable and swift early CRC diagnosis and prognosis, providing, in turn, opportunities for novel and innovative technologies such as CRISPR-Dx platforms to aid clinical diagnosis efforts.

\section{CRISPR/Cas Systems}

CRISPR/Cas systems arrange and shape the prokaryotic adaptative immunity and immune memory by acquiring foreign viral genetic material, namely spacers, and using them later to resist invasion $[157,158]$. Accordingly, CRISPR/Cas classification is made up of Class I (including type I, III, and IV) and Class II (including type II, V, and VI), where both class types currently have 33 characterized subtypes in total [159]. Interestingly, CRISPR/Cas systems are incredibly diverse, which may be explained due to the continuous encounters with different viruses throughout time, driving towards competitive coevolution [160,161].

CRISPR/Cas immune response against viral invasion has three key stages: adaptation, expression, and interference. During the adaptation process, Cas proteins detect their target DNA/RNA (known as protospacer), recognized by a protospacer-adjacent motif (PAM, DNA target) or protospacer flanking site (PFS, RNA target) depending on the Cas effector. Then, Cas proteins bind to the target DNA/RNA to update their immune memory bank, integrate the foreign DNA sequences into the CRISPR array, and acquire a new spacer [162]. In RNA acquisition, a retro-transcription of the target is performed before spacer acquisition and integration into the CRISPR array [163]. 
The CRISPR array is then expressed as a premature crRNA (pre-crRNA) that will mature and generate a crRNA via either Cas proteins or host factors. This crRNA (often named as gRNA) will then complex with a Cas protein to rise an effector complex and perform the interference stage, which involves the target nucleic acid cognation, binding (tertiary complex), and cleavage, ultimately degrading their target and preventing further exogenous host invasion. Therefore, CRISPR/Cas is a sophisticated RNA-guided adaptative immunity system based on a molecular nucleic acid memory (further in-depth revision of CRISPR/Cas immune acquisition and response process can be found in [157-164]).

Hence, it is important to highlight that Class 1 systems are based on multiple effector modules with several different Cas proteins to provide bacteria and archaea with the adaptative immunity stages. In contrast, Class 2 systems comprise single, multidomain Cas proteins (e.g., Cas9, Cas12, and Cas13) containing all necessary domains and activity to carry the target cleavage, i.e., interference. In some subtypes, some Cas proteins also provide pre-crRNA processing [85], rendering Class 2 systems as straightforward molecular mechanisms to harness and establish molecular detection tools.

Indeed, since the renowned study published by Jinek et al. [165], which showed CRISPR/Cas9 as a new dual-RNA-guided genetic engineering tool capable of precisely performing double-stranded DNA (dsDNA) cleavage, this technology has broadly led to the well-known CRISPR revolution due to its ease of use, versatility, and high efficiency to generate permanent genetic changes on its target, therefore, it was swiftly implemented in several studies on animal and cellular models [157]. Moreover, harnessing CRISPR/Cas9 versatility, it has also been engineered to work as a transcriptional regulator [166], DNA labeler [167], and nucleic acid detector [168]. Thus, the CRISPR/Cas9 toolbox has enabled promising advances, including breast cancer modelling in mice [169], potential CRISPRbased treatments [170], interrogation of mechanisms in ovarian cancer [171], epigenetic control of pancreatic cancer [172], targeted tumor regression [173], and lung cancer miRNA detection [174]. Moreover, CRISPR/Cas technology has recently obtained a considerable milestone in in vivo gene editing to treat transthyretin amyloidosis, achieving the first direct body bloodstream deployment of lipid nanoparticles encapsulating CRISPR/Cas9 mRNA (i.e., Cas9 and gRNA) to safely decline the synthesis of the TTR protein associated with the disease by an average of $87 \%$, whereas conventional methods report up to a $80 \%$ TTR synthesis decline [175-177]. Indeed, this new CRISPR/Cas landmark registers an important precedent that may be applicable to treat other diseases, including enhanced CRISPR/Cas-based therapies for cancer.

The characterization of the mechanism of action and potential uses of the CRISPR/Cas9 system resulted in the 2020 Chemistry Nobel Prize being awarded to Jennifer Doudna and Emmanuelle Charpentier. However, since its origin, the CRISPR revolution has gone far beyond its use as a genetic engineering tool. New Cas endonucleases have been characterized and have expanded CRISPR/Cas technologies towards novel nucleic acid-based molecular diagnostics, with swift, ultrasensitive, and inexpensive diagnostic platforms, thus branching out to a CRISPR-Dx revolution with versatile next-generation molecular biosensing platforms $[29,178]$.

CRISPR-Dx is mainly led by two Class 2 endonucleases, Cas12 and Cas13, which bind and cleave DNA and RNA, respectively. They both have a cis cleavage mechanism of action, i.e., degradation of the main DNA/RNA target. However, they have also been reported to exhibit a target-activated trans collateral cleavage capable of degrading short sequences of dsDNA or single-stranded RNA (ssRNA), respectively, triggered upon target detection and cis cleavage [21,31] (see Figure 3). Thus, these natural Cas12 and Cas13 properties have been quickly harnessed to establish molecular diagnosis tools based on rapid and specific nucleic acid detection mediated mainly through FQR [22,25]. Accordingly, Cas12 trans collateral activity has a cis:trans enzymatical kinetic ratio of 1:1250 per second, showcasing a natural signal amplification of the detection performed [31]. Regarding Cas13, there are no similar studies done on the most widely used type of Leptotrichia wadei Cas13 (LwaCas13a); however, inferring from their similar sensitivity (aM 
vs. $\mathrm{zM}$, with previous amplification), the LwaCas13a cis:trans kinetic ratio might be similar or higher [22]. Accordingly, Shan et al. [179] reported that Leptotrichia buccalis Cas13a (LbuCas13a) had shown a cis:trans cleavage ratio of 1:4854 per second with a sensitivity reaching the $1 \mathrm{pM}$ range (no previous amplification). Therefore, Cas12 and Cas13 are not only natural beacon-like reporters, but they also intrinsically amplify the detection signal mediated by their trans-collateral activity. Although Cas9 does not exhibit any transcollateral activity (see Figure 3), there have been some CRISPR/Cas9-based platforms, including lateral flow detection [180] and fluorescence readouts [181], which display a good detection performance for the CRISPR-Dx toolbox; however, the implementation may have drawbacks due to logical adjustment of Cas9 to transform it into a functional molecular detector, including less cost-effectiveness due to the requirement of antibodies, fluorescent probes, and extra enzymes, which also leads to complications for setup.

\section{CRISPR/Cas endonucleases}

\section{Cas9}

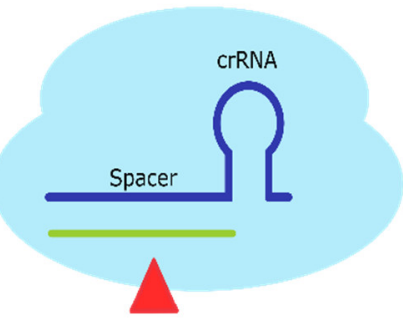

- No trans-cleavage.

- PAM restriction.

- Spacer size (16 to $20 \mathrm{nt}$ ).

- dsDNA targets (no secondary structures target restriction).

\section{Cas12}

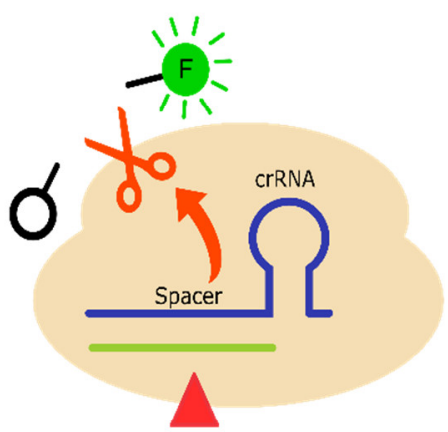

- Non-specific trans-cleavage (dsDNA FQR).

- PAM restriction.

- Spacer size (16 to $25 \mathrm{nt}$ ).

- dsDNA targets (no secondary structures target restriction).
Cas13

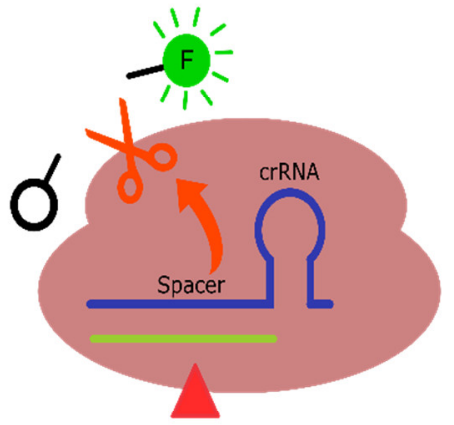

- Semi-specific trans-cleavage (ssRNA

FQR).

- PFS restriction*

- Spacer size (20 to $30 \mathrm{nt}$ ).

- ssRNA targets (target secondary

structures restriction).

Figure 3. CRISPR/Cas endonucleases. Cas9, Cas12, and Cas13 endonucleases are illustrated. Cas9 and Cas 12 cis activity cleaves dsDNA. Cas13 cis activity cleaves linear ssRNA. Cas9 does not exhibit any detectable trans-cleavage activity. Cas12 and Cas13 exhibit trans-collateral activity capable of cleaving non-specific dsDNA/semi-specific ssRNA FQR, respectively. Cas 9 and Cas12 do not have target secondary structure restrictions, while Cas13 has target secondary structure restrictions since it only can cleave linear ssRNA [31,182,183]. * Some Cas13 endonucleases exhibit no PFS restrictions [184].

Further characterization has been performed on Cas12 and Cas13 subtypes and orthologs, observing that Cas12 trans dsDNA cleavage preference is non-specific [31]. In contrast, Cas13 trans ssRNA cleavage has shown a di-nucleotide motif preference, which varies depending on the Cas13 ortholog [22], allowing multitarget detection, considerably increasing its applicability for molecular diagnosis, especially when several targets must be identified simultaneously within a single sample. Additionally, Cas13 is customizable in terms of portability and one-step reactions maintaining its swiftness, robustness, and sensitivity [22,24]. Therefore, Cas13 and its orthologs (e.g., LwaCas13a, LbuCas13a) represent the best potential candidates among Cas endonucleases to fulfill miRNA-based diagnosis requirements and tackle current challenges for CRC early diagnosis and prognosis, which may also benefit other types of cancer that also have miRNAs as potential diagnosis molecules.

CRISPR/Cas13's excellent diagnosis capabilities have been proposed and used in several other fields, including SARS-CoV-2 detection [185], food pathogens [186], and environmental biomonitoring and surveillance $[187,188]$. Interestingly, as CRISPR/Cas 
technology applicability increases, novel Cas endonucleases are characterized and added to the CRISPR/Cas toolbox [189]. For example, Cas13d has been recently characterized with similar properties to Cas13a, b and c, but with a molecular weight of approximately two-thirds of its predecessors' molecular weight [184], which may facilitate its expression and reduce overall enzyme production costs for future applications.

Moreover, CRISPR/Cas systems have also been characterized within genomes of huge bacteriophages, namely CRISPR-Cas $\Phi$ [190], which further expands the CRISPR-Dx toolbox. Accordingly, there is no doubt that considering the bacterial biodiversity (and now viral) there will be several new Cas endonucleases discoveries that may further expand and enhance the current CRISPR/Cas toolbox towards innovative or enhanced functionalities.

\section{CRISPR/Cas13-Based Platforms as a Potential Candidate for CRC Early Diagnosis and Prognosis}

Although most CRISPR/Cas13-based molecular platforms have not yet been broadly used on miRNAs (see Table 4), they portray potential opportunities for CRC and cancer early diagnosis and prognosis from either CEx-miRNAs or cf-miRNAs. CRC has been shown as a worldwide epidemy, and complementary tools currently need to be enhanced to provide primary, secondary, and tertiary prevention to patients. We propose that CRISPR/Cas13-based diagnosis can play a pivotal role in helping secondary prevention measures to meet current needs for CRC early diagnosis and prognosis, whereas early screenings have been shown to help assess and reduce CRC mortality [191]. Accordingly, CRISPR/Cas13-based platforms may also help to provide a better quality of life of the patients with tertiary prevention, playing a role for patients' prognosis and providing medical teams with data that support the best decision-making process to deliver adequate therapies.

Table 4. Promising molecular CRISPR/Cas13-based platforms for CRC early diagnosis and prognosis showcasing potential applicability and technological accessibility.

\begin{tabular}{|c|c|c|c|c|c|c|c|}
\hline Methods $^{\text {a }}$ & Target & $\begin{array}{l}\text { Pre-Amplification } \\
\text { (Method) }\end{array}$ & Sensitivity ${ }^{b}$ & $\underset{\text { (min) }}{\text { Runtime }}$ & Multiplexation & Readout & Reference \\
\hline \multicolumn{8}{|l|}{$\begin{array}{l}\text { miRNA targets } \\
\text { approach }\end{array}$} \\
\hline CRISPR/LbuCas13a & miRNAs & $\mathrm{N}$ & $5 \mathrm{pM}$ & 30 & $\mathrm{~N}$ & $\mathrm{~F}$ & [179] \\
\hline \multicolumn{8}{|l|}{$\begin{array}{c}\text { non-miRNA targets } \\
\text { approach }\end{array}$} \\
\hline SHERLOCK & ST & Y (RPA) & $2 \mathrm{aM}$ & 120 & $\mathrm{~N}$ & $\mathrm{~F}$ & [21] \\
\hline SHERLOCKv2 & ST & Y (RPA) & $8 \mathrm{zM}$ & 30 & $Y(4)$ & $\mathrm{F} / \mathrm{S}$ & [22] \\
\hline HUDSON & ST & Y (RPA) & $0.9 \mathrm{aM}$ & 120 & $\mathrm{~N}$ & $\mathrm{~F} / \mathrm{S}$ & [26] \\
\hline CARMEN-Cas13 & $\begin{array}{c}\text { Viral } \\
\text { particles }\end{array}$ & Y (PCR) & $2 \mathrm{aM}$ & $30-180$ & Y (169) & $\mathrm{F}$ & [192] \\
\hline SATORI & SARS-CoV-2 & $\mathrm{N}$ & $5 \mathrm{fM}$ & $5-10$ & $\mathrm{~N}$ & $\mathrm{~F}$ & [193] \\
\hline
\end{tabular}

$\mathrm{Y}=$ Yes; $\mathrm{N}=\mathrm{No} ; \mathrm{F}$ = fluorescence; $\mathrm{S}$ = lateral flow strip; $\mathrm{ST}$ = synthetic target. SHERLOCK = specific high sensitivity enzymatic reporter unlocking; HUDSON = heating unextracted diagnostic samples to obliterate nucleases; CARMEN = combinatorial arrayed reactions for multiplexed evaluation of nucleic acids; SATORI $=$ CRISPR-based amplification-free digital RNA detection. ${ }^{a}$ All methods reported single nucleotide, with the exception of SATORI. bfM = 10-15 mol L-1; aM = 10-18 mol L-1; zM = 10-21 mol L-1. An in-depth review of the CRIPSR/Cas13 nucleic acid detection tool and other Cas endonucleases can be found in [85]

The SHERLOCK platform was the first CRISPR/Cas13 molecular detection tool where Gootenberg et al. [21] showcased CRISPR/Cas technologies as a versatile diagnostic tool and paved the way for the CRISPR-Dx revolution. In the first instance, SHERLOCK only harnessed LwaCas13a nucleic acid detection capabilities, obtaining single-nucleotide resolution with 2 aM sensitivity within $2 \mathrm{~h}$. However, this platform was quickly enhanced the following year, presented as SHERLOCKv2 [22], with several breakthroughs coupling Cas13 reaction with an isothermal amplification method dubbed recombinase polymerase reaction (RPA), obtaining significant enhancements including inexpensive $\mathrm{zM}$ sensitivity with linear, quantifiable results, reaching up to aM-zM sensitivity with a cost of USD 0,6 
per sample, 30 min one-step runs, four-channel targets detection via multiplexing three Cas13 orthologs and one Cas12 enzyme, and a strip-based test with lateral flow readout, therefore providing an accessible and versatile portable nucleic acid platform.

SHERLOCK diagnosis was then further optimized for clinical samples with a special protocol termed HUDSON [26], enabling SHERLOCK to pair with instrument-free detection directly from patient fluid samples including blood and saliva in less than $2 \mathrm{~h}$, thus proving Cas 13 to be a robust endonuclease for direct analysis on unextracted samples. Another improvement of SHERLOCK was then developed by Ackerman et al. [192], where CARMEN-Cas13 represented the first use of SHERLOCK on a larger scale, managing the detection of 169 viruses simultaneously through 4500 crRNAs constructs through nanoliter droplets organized as a microarray plate. Moreover, CARMEN-Cas13 maintains ultrasensitive SHERLOCK properties and further increases cost-effectiveness by decreasing 300 -fold overall reagents costs, further demonstrating CRISPR/Cas13 as a valuable tool for early CRC diagnosis.

Recently, Cas13 systems have been further enhanced to enable a microfluidic-based system known as SATORI [193]. Although it represents a significant drop in sensitivity due to there being no isothermal amplification, it reached single-molecule resolution at approximately $5 \mathrm{fM}$. This sensitivity is obtained through a microchamber-array configuration which allows detection in less than $5 \mathrm{~min}$ with high specificity, positioning SATORI as a top-class, quick diagnostic tool that may also serve for CRC diagnosis and prognosis, especially for CRC-POC diagnosis efforts.

There are also reports exploiting Cas13 trans-cleavage properties for miRNAs detection (see Table 4, miRNA targets approach section). Shan et al. [179] harnessed LbuCas13 to directly detect miRNA-17, obtaining high specificity and a $1 \mathrm{pM}$ sensitivity range with crRNA spacer constructs ranging from $20 \mathrm{nt}$ to $28 \mathrm{nt}$ in $30 \mathrm{~min}$ runs. Moreover, they further tested Cas13 systems specificity, evidencing its robust single-nucleotide resolution, efficiently differentiating miR-17, miR-106a, miR-20a, and miR-20b, which have 1 to $2 \mathrm{nt}$ of difference, accordingly, showcasing CRISPR/Cas13-based platforms with great applicability and fidelity for multiplexed detection of highly similar miRNAs. Similar results were reported on miR-17 by Sha et al. [194], although they used a cascade CRISPR/Cas system, harnessing Cas13 and Cas14 endonucleases, obtaining a sensitivity of $1.33 \mathrm{fM}$ in $15 \mathrm{~min}$. However, due to the use of Cas14 as the detection molecule and Cas13 as an intermediary enzyme for the activation of a probe, multiplexation is not an option because, similarly to Cas12, Cas14 has a non-specific trans-collateral DNAse activity [159]. Another study coupled CRISPR/Cas13a to an electrochemical assay for microRNA-21 detection with a sensitivity of $2.6 \mathrm{fM}$ in $60 \mathrm{~min}$ [195]. Nevertheless, the complete assay setup and configuration may be complex and labour intensive to construct, including the Au electrode preparation and catalytic hairpin assembly design.

It is essential to mention that there are other studies applying CRISPR/Cas13 for miRNA diagnosis, including electrochemical approaches [196] and electrochemiluminescence chip [197]. Although these systems show great results and efficiency, the configuration and construction of the assays are complex and require expert setup, reducing CRISPR/Cas13 applicability and technological accessibility for users and stakeholders. Thus, based on the available information, the most accessible systems are listed in Table 5. These methods remain quick and straightforward to setup, without compromising their overall efficiency regarding specificity and sensitivity. It is important to highlight an issue between miRNA size (18 to $24 \mathrm{nt}$ ) and Cas13 spacer size (20 to $28 \mathrm{nt}$ ). However, there are a few approaches that may solve this issue, which are mentioned in the next section.

Moreover, there is a need for research on rapid and reliable miRNA extraction methods similar to the HUDSON protocol for clinical bodily fluids such as blood and saliva. Furthermore, based on the observation of robust detection on raw clinical and environmental samples [26,187], where PCR-based configuration may not work properly due to high concentration of potential inhibitors, CRISPR/Cas13 also represents an opportunity to detect miRNA from raw or rapidly-processed samples, further facilitating sample management. 
Table 5. CRC CEx-miRNAs panels for direct multiplex and singleplex approaches of CRISPR/Cas13-based diagnosis.

\begin{tabular}{|c|c|c|c|c|}
\hline miRNA & crRNA Sequence $^{a}$ & $\begin{array}{l}\text { Cas13 Ortholog } \\
\text { (Spacer Length) }\end{array}$ & Associated FQR & Reference \\
\hline \multicolumn{5}{|c|}{ Multiplex approach ${ }^{b}$} \\
\hline miR-126-3p & $\begin{array}{l}\text { \{GAU UUA GAC UAC CCC AAA } \\
\text { AAC GAA GGG GAC UAA } \\
\text { AAC\}-[AGC AUG GCA CUC } \\
\text { AUU AUU ACG C (uuu uuu)] }\end{array}$ & LwaCas13a (28 nt) & $\mathrm{F} / / \mathrm{T}^{*} \mathrm{~A}^{*} \mathrm{rArUG}{ }^{*} \mathrm{C} / / \mathrm{Q}$ & {$[24,136,197]$} \\
\hline miR-1290 & $\begin{array}{l}\text { \{GUU GAU GAG AAG AGC CCA } \\
\text { AGA UAG AGG GCA AUA } \\
\text { AC\}-[ACC UAA AAA CCU AGU } \\
\text { CCC U (uuu uuu uuu)] }\end{array}$ & LbaCas13a (28 nt) & $\mathrm{F} / / \mathrm{T}^{*} \mathrm{~A}^{*} \mathrm{rUrAC} \mathrm{C}^{*} \mathrm{C}^{*} / / \mathrm{Q}$ & {$[24,136,197]$} \\
\hline miR-23a-3p & $\begin{array}{c}\text { [UAG UGU AAC GGU CCC UAA } \\
\text { AGG (uuu uuu uuu)]-\{GUU GUA } \\
\text { GAA GCU UAU CGU UUG GAU } \\
\text { AGG UAU GAC AAC }\}\end{array}$ & CcaCas13b (30 nt) & $\mathrm{F} / / \mathrm{T}^{*} \mathrm{~A}^{*} \mathrm{rUrAG} \mathrm{G}^{*} \mathrm{C}^{*} / / \mathrm{Q}$ & {$[24,136,197]$} \\
\hline miR-940 & $\begin{array}{l}\text { [UUC CGU CCC GGG GGC GAG } \\
\text { GGG (uuu uuu uuu)]-\{GUU GUA } \\
\text { GAA GCU UAU CGU UUG GAU } \\
\text { AGG UAU GAC AAC\} }\end{array}$ & PsmCas13b (30 nt) & $\mathrm{F} / / \mathrm{rArArArArA} / / \mathrm{Q}$ & {$[24,136,197]$} \\
\hline \multicolumn{5}{|c|}{ Singleplex approach $^{\mathrm{c}}$} \\
\hline miR-126-3p & $\begin{array}{c}\text { \{GAU UUA GAC UAC CCC AAA } \\
\text { AAC GAA GGG GAC UAA } \\
\text { AAC\}-[AGC AUG GCA CUC } \\
\text { AUU AUU ACG C (uuu uuu)] }\end{array}$ & LwaCas13a (28 nt) & $\mathrm{F} / / \mathrm{T}^{*} \mathrm{~A}^{*} \mathrm{rArUG} \mathrm{A}^{*} \mathrm{C} / / \mathrm{Q}$ & {$[24,136,197]$} \\
\hline miR-1290 & $\begin{array}{c}\text { \{GAU UUA GAC UAC CCC AAA } \\
\text { AAC GAA GGG GAC UAA } \\
\text { AAC\}-[ACC UAA AAA CCU } \\
\text { AGU CCC U (uuu uuu uuu)] }\end{array}$ & LwaCas13a (28 nt) & $\mathrm{F} / / \mathrm{T}^{*} \mathrm{~A}^{*} \mathrm{rArUG}{ }^{*} \mathrm{C} / / \mathrm{Q}$ & {$[24,136,197]$} \\
\hline miR-23a-3p & $\begin{array}{c}\text { \{GAU UUA GAC UAC CCC AAA } \\
\text { AAC GAA GGG GAC UAA } \\
\text { AAC\}-[UAG UGU AAC GGU } \\
\text { CCC UAA AGG (uuu uuu u)] }\end{array}$ & LwaCas13a (28 nt) & $\mathrm{F} / / \mathrm{T}^{*} \mathrm{~A}^{*} \mathrm{rArUG}{ }^{*} \mathrm{C} / / \mathrm{Q}$ & {$[24,136,197]$} \\
\hline miR-940 & $\begin{array}{c}\text { \{GAU UUA GAC UAC CCC AAA } \\
\text { AAC GAA GGG GAC UAA } \\
\text { AAC\}-[UUC CGU CCC GGG } \\
\text { GGC GAG GGG (uuu uuu u)] }\end{array}$ & LwaCas13a (28 nt) & $\mathrm{F} / / \mathrm{T}^{*} \mathrm{~A}^{*} \mathrm{rArUG}{ }^{*} \mathrm{C} / / \mathrm{Q}$ & {$[24,136,197]$} \\
\hline
\end{tabular}

$\mathrm{F}$ = fluorophore; $\mathrm{nt}=$ nucleotides; $\mathrm{Q}=$ quencher; $\mathrm{r}=$ ribonucleotide; $\mathrm{Lba}=$ Lachnospiraceae bacterium $\mathrm{NK} 4 \mathrm{~A} 179 ;$ Cca $=$ Capnocytophaga canimorsus Cc5; Psm = Prevotella sp. MA2016; $\mathrm{T}^{*}, \mathrm{~A}^{*}, \mathrm{C}^{*}$ or $\mathrm{G}^{*}$ are phosphorothioate modifications. ${ }^{\text {a }}$ Sequences between \{\} are the direct repeat sequences from each Cas13 endonuclease ortholog. Sequences between [] are spacer regions complementary to the miRNA sequence accession number given in Table 3 that have been ligated to a poly A/T universal tag at their $3^{\prime}$ end denoted between () to increase target length towards 28 or $30 \mathrm{nt}$ according to the Cas endonuclease proposed. Note that the spacer sequence is complementary to the target miRNAs. Where miR-3p/5p was not mentioned, we have used the $3 p / 5 p$ with higher reads as a standard annotation for the proposed designs. ${ }^{b}$ Multiplex approach. Simultaneous detections from a single sample in a single tube. ${ }^{c}$ Singleplex approach. Simultaneous detections from a single sample in multiple tubes.

\section{Dedicated crRNA Design for a Potential CRISPR/Cas13-Based Platform for CRC miRNAs-Based Diagnosis}

To further facilitate and streamline the research and use of CRISPR/Cas13-based diagnosis and prognosis for CRC through CEx-miRNAs or cf-miRNAs, we have built a potential candidate miRNAs panel from Table 3 (best AUC reported on CRC T stage) with their respective crRNA design (see Table 5). Furthermore, several reports on miRNA detection methods, including RPA [198] and polyA/T universal tag [198,199], have not been merged with CRISPR/Cas13 for miRNA detection but represent simple approaches to solving the issue of miRNA and the corresponding spacer size. 
There are two main approaches for direct CRISPR/Cas13-based CRC diagnosis (Table 5). (1) The multiplex approach, which can be obtained harnessing the di-nucleotide motif preference of each Cas13 ortholog to simultaneously detect four targets at once from a unique sample with the same detection properties [21,22]; however, only LwaCas13a is commercially available meanwhile other Cas13 endonucleases are only available as a plasmid construct. Thus, they need to be expressed and purified, which may result to be slow and expensive. (2) The singleplex approach, using only LwaCas13a, may be more achievable since numerous studies use it $[21,22,185,187,192,200]$, showcasing a solid reproducibility.

However, these studies use intra-lab-expressed LwaCas13a and are not commercially obtained; instead, they are obtained as plasmid constructs from Addgene [201]. There are also companies selling LwaCas13a from 85 to $95 \%$ purity, similar to purity qualities obtained in previously mentioned studies. Accordingly, singleplex is currently the more affordable and promising miRNAs-based diagnosis approach due to the commercial accessibility of LwaCas13a. Meanwhile, although the multiplex approach is also promising and needed to solve CRC diagnosis challenges, using several Cas13 orthologs through plasmid expression constructs may be inconvenient due to several factors, including the need for specialized equipment and potential cross-contaminations during the overall process.

Furthermore, multiplex and singleplex crRNA designs approaches can be followed using polyA/T universal tag as shown in Table 5 to comply with the spacer size of 20 to $30 \mathrm{nt}$ and achieve direct Cas $13 \mathrm{miRNAs}$ detection in 30 to $45 \mathrm{~min}$. Another potential approach can be made by coupling the RPA amplification step with annealing probes that also increase template size to comply with Cas13 crRNA spacer requirements [22]. However, Cas13 needs RNA targets, and to fulfill this requirement, RT-RPA can be followed with an in vitro transcription (IVT) to obtain the RNA template for Cas13. Thus, a SHERLOCK-based procedure may be implemented to run RT-RPA, IVT, and Cas13 reactions simultaneously (see Figure 4) to detect CRC-related miRNAs reported previously and provide results in 15 to $30 \mathrm{~min}$ [22] (Tables 4 and 5). Therefore, this can be useful to expedite the diagnosis and prognosis turnaround for the medical decision-making process since SHERLOCK has a run time range from 15 to $30 \mathrm{~min}$, without considering sample extraction procedures. In this regard, taking into consideration that CEx-miRNAs have shown the best results, it is pivotal to mention that the best-reported source of CEx-miRNAs from available commercial kits is blood serum, in terms of abundancy. Meanwhile, miRNA quality performed well within all used blood exosome kits extraction [202].

The difference in the turnaround time of the detection between both approaches presented in Figure 4 can be explained due to RPA, whereby it increases Cas 13 targets significantly through isothermal amplification. Moreover, in terms of portability, SHERLOCKbased miRNA detection is higher as the probe ligation before RT-RPA can be performed at $37^{\circ} \mathrm{C}$, as with the rest of the process, further facilitating its configuration and platform accessibility, enabling a potential establishment of POC diagnosis and prognosis for CRC risk patients based on CRISPR-Dx technologies. Therefore, based on the presented evidence, both approaches may represent a fast route to establish a scalable, early diagnosis protocol for CRC from its cf-miRNAs /CEx-miRNAs biomarkers (e.g., miR-126, miR-1290); thus, this may set fundamental pillars for future implementations of other CRISPR/Cas13 in CRC diagnosis efforts. 


\section{crRNA-miRNA detection concept}

A
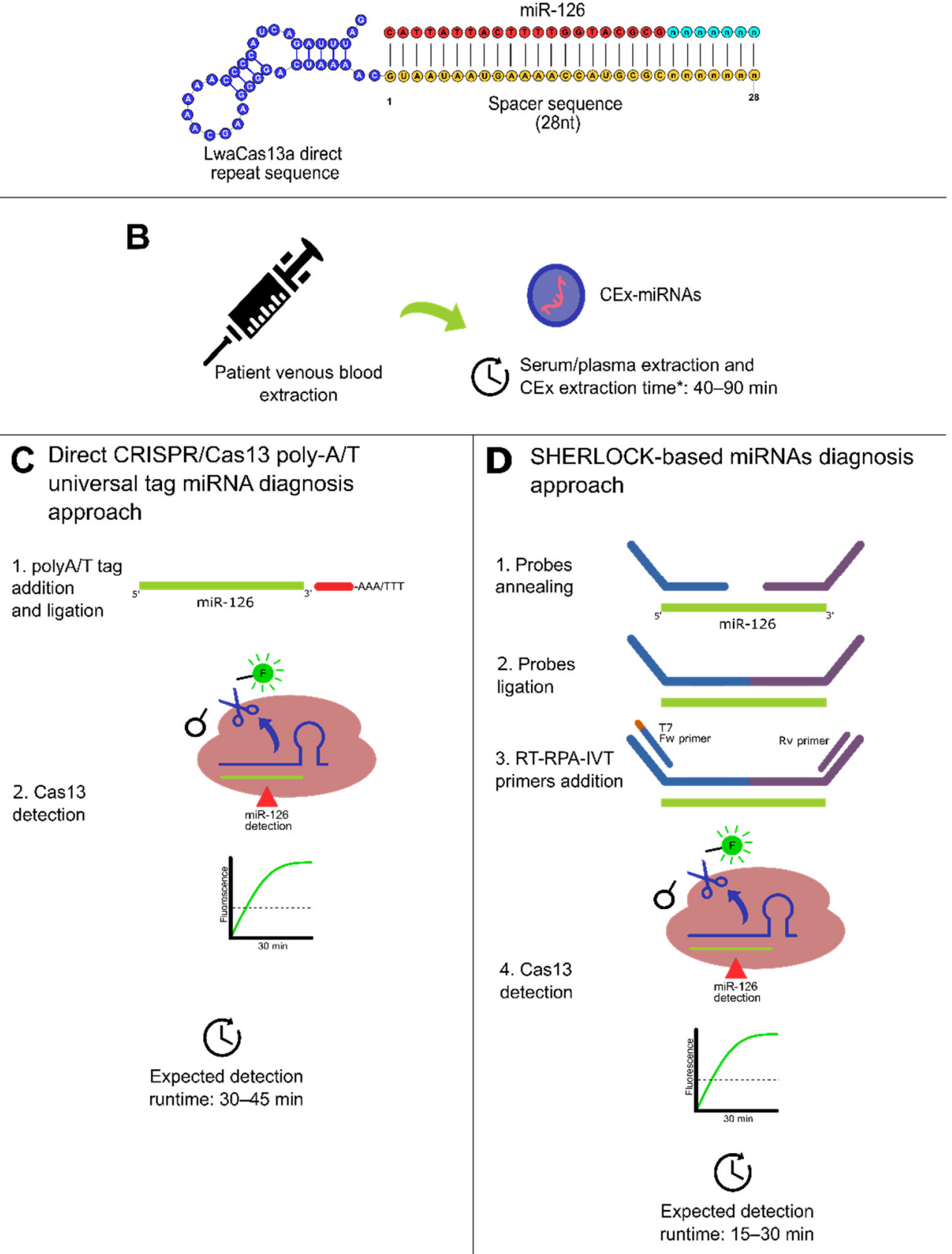

Figure 4. Dedicated CRISPR/Cas13-based miRNA diagnosis approaches. * Additional 30 min were added to consider miRNA extraction from exosomes. (A) Conceptual crRNA (direct repeat blue; spacer region: yellow; protospacer: red and cyan). (B) Obtention of peripheral blood from patients and CEx-miRNAs timeframe conceptualization based on [202]. (C) Direct CRISPR/Cas13 direct approach detection for diagnosis using a poly-A/T universal tag for CEx-miRNAs with a theoretical 2-steps method based on [178]. This approach may be suitable for highly abundant CEx-miRNAs targets. (D) A SHERLOCK-based diagnosis approach with a theoretical 4-steps method based on [22]. This approach may be suitable for high/low abundant CEx-miRNAs targets. For both cases (C,D), runtimes do not consider sample isolation and purification. Moreover, polyA/T ligation may need high temperatures. 


\section{Conclusions}

CRC is currently a worldwide known epidemy in developed countries, whereas its prevalence and mortality are increasing yearly. To halt its advance and provide quality healthcare, there is a need to strengthen and reinforce current traditional medical surveillance programs mainly based on invasive methods such as colonoscopies or molecular methods primarily based on RT-qPCR, where both have challenges and limitations.

Recently, promising studies have revealed that CRC and other cancers actively release/secrete EVs, especially CEx, which are basically intercellular communication vehicles with rich molecular cargo, including DNA, RNA, and proteins. Accordingly, CEx cargo includes miRNA, which regulates different carcinogenic physiological behaviors, including tumor progression and angiogenesis. Therein, CExs-miRNA has been reported as a potential biomarker with robust predictive results of diagnosis and prognosis.

Although the primary tool for CEx-miRNAs detection is RT-qPCR, alternative emerging molecular methods such as CRISPR-Dx technologies may potentially benefit and complement current established secondary prevention measures with cost-effective molecular early screenings. Moreover, due to the inherent ease of use, robustness, scalability and portability of CRISPR/Cas13-based detection platforms previously shown, this ultrasensitive technology may be further developed to deliver early POC diagnosis and prognosis to CRC risk patients with affordable rates and swift turnaround times, allowing healthcare teams to have reliable data to deliver the optimal treatment on time and reduce the risks of late CRC stages diagnosis which have low five-year survival rates.

Moreover, this study may also streamline future research and proof-of-concept of CRISPR/Cas13-based platforms for miRNA detection for early diagnosis and prognosis with proposed methodologies based on direct CRISPR/Cas13-miRNA detection or SHERLOCK-based miRNA detection to further enhance and facilitate CEx-miRNAs detection in minimally invasive methods, i.e., blood samples (serum) based on a CExmiRNAs panel including miR-126, miR-1290, miR-23a, and miR-940, which have shown to date the best predictive data for early CRC stages. Thus, from the gathered evidence, CRISPR/Cas13-based platforms represent promising potential for early, next-generation CRC diagnosis and prognosis candidates, where their intrinsic features may also be appealing for the diagnosis and prognosis efforts for other types of cancers.

Author Contributions: Conceptualization, B.D.-V., and K.A.-C.; writing-original draft preparation, B.D.-V., K.A.-C., L.V., J.C., H.W., and P.L.-R.; writing-review and editing, B.D.-V., K.A.-C., L.V., J.C., J.R., P.A.-C., and P.L.-R.; supervision, H.W., and P.L.-R.; project administration, B.D.-V., J.C., H.W., and P.L.-R.; funding acquisition, B.D.-V., H.W., and P.L.-R. All authors have read and agreed to the published version of the manuscript.

Funding: P.L.-R., L.V., and B.D.-V. thank the National Agency for Research and Development (ANID) for funding in the context of the Grant Fondecyt \#1201734. K.A.-C. and B.D.-V. also thank ANID for funding in the context of the Grant Valorization of the University Research Program (FONDEF-VIU; VIU20P0030). J.C. also thanks ANID for funding in the context of the Grant Fondequip EQM190110 and the Grant Fondecyt \#11170353. H.W. thanks ANID for funding in the context of the Grant Fondecyt \#11180987.

Institutional Review Board Statement: Not applicable.

Informed Consent Statement: Not applicable.

Data Availability Statement: No new data were created or analyzed in this study. Data sharing is not applicable to this article.

Acknowledgments: All authors thank the Universidad de La Frontera and Universidad del Desarollo for supporting the aforementioned projects.

Conflicts of Interest: The authors declare no conflict of interest. The funders had no role in the design of the study; in the collection, analyses, or interpretation of data; in the writing of the manuscript, or in the decision to publish the results. 


\section{References}

1. Lauby-Secretan, B.; Vilahur, N.; Bianchini, F.; Guha, N.; Straif, K.; International Agency for Research on Cancer Handbook Working Group. The IARC perspective on colorectal cancer screening. N. Engl. J. Med. 2018, 378, 1734-1740. [CrossRef] [PubMed]

2. Barani, M.; Bilal, M.; Rahdar, A.; Arshad, R.; Kumar, A.; Hamishekar, H.; Kyzas, G.Z. Nanodiagnosis and nanotreatment of colorectal cancer: An overview. J. Nanopart. Res. 2021, 23, 18. [CrossRef]

3. Bray, F.; Ferlay, J.; Soerjomataram, I.; Siegel, R.L.; Torre, L.A.; Jemal, A. Global cancer statistics 2018: GLOBOCAN estimates of incidence and mortality worldwide for 36 cancers in 185 countries. CA Cancer J. Clin. 2018, 68, 394-424. [CrossRef]

4. Dekker, E.; Tanis, P.J.; Vleugels, J.L.A.; Kasi, P.M.; Wallace, M.B. Colorectal cancer. Lancet 2019, 394, 1467-1480. [CrossRef]

5. Angell, H.K.; Bruni, D.; Barrett, J.C.; Herbst, R.; Galon, J. The immunoscore: Colon cancer and beyond. Clin. Cancer Res. 2020, 26, 332-339. [CrossRef]

6. Zarour, L.R.; Anand, S.; Billingsley, K.G.; Bisson, W.H.; Cercek, A.; Clarke, M.F.; Coussens, L.M.; Gast, C.E.; Geltzeiler, C.B.; Hansen, L.; et al. Colorectal Cancer Liver Metastasis: Evolving Paradigms and Future Directions. Cell. Mol. Gastroenterol. Hepatol. 2017, 3, 163-173. [CrossRef]

7. Koliarakis, I.; Messaritakis, I.; Nikolouzakis, T.K.; Hamilos, G.; Souglakos, J.; Tsiaoussis, J. Oral bacteria and intestinal dysbiosis in colorectal cancer. Int. J. Mol. Sci. 2019, 20, 4146. [CrossRef]

8. $\quad$ Lew, J.-B.; Feletto, E.; Wade, S.; Caruana, M.; Kang, Y.-J.; Nickson, J.; Simms, K.T.; Procopio, P.; Taylor, N.; Worthington, J.; et al. Benefits, harms and cost-effectiveness of cancer screening in Australia: An overview of modelling es-timates. Public Health Res. Pract. 2019, 29, 29121913. [CrossRef] [PubMed]

9. Xie, Y.-H.; Chen, Y.-X.; Fang, J.-Y. Comprehensive review of targeted therapy for colorectal cancer. Signal Transduct. Target Ther. 2020, 5, 22. [CrossRef] [PubMed]

10. Gungormez, C.; Aktas, H.; Dilsiz, N.; Borazan, E. Novel miRNAs as potential biomarkers in stage II colon cancer: Microarray analysis. Mol. Biol. Rep. 2019, 46, 4175-4183. [CrossRef]

11. Chen, W.-Y.; Zhao, X.-J.; Yu, Z.-F.; Hu, F.-L.; Liu, Y.-P.; Cui, B.-B.; Dong, X.-S.; Zhao, Y.S. The potential of plasma miRNAs for diagnosis and risk estimation of colorectal cancer. Int. J. Clin. Exp. Pathol. 2015, 8, 7092-7101.

12. Hibner, G.; Kimsa-Furdzik, M.; Francuz, T. Relevance of MicroRNAs as potential diagnostic and prognostic markers in colo-rectal cancer. Int. J. Mol. Sci. 2018, 19, 2944. [CrossRef] [PubMed]

13. Carter, J.V.; Galbraith, N.J.; Yang, D.; Burton, J.F.; Walker, S.P.; Galandiuk, S. Blood-based microRNAs as biomarkers for the diagnosis of colorectal cancer: A systematic review and meta-analysis. Br. J. Cancer 2017, 116, 762-774. [CrossRef]

14. Desmond, B.J.; Dennett, E.R.; Danielson, K.M. Circulating extracellular vesicle microRNA as diagnostic biomarkers in early colorectal cancer-A review. Cancers 2020, 12, 52. [CrossRef] [PubMed]

15. Min, L.; Zhu, S.; Chen, L.; Liu, X.; Wei, R.; Zhao, L.; Yang, Y.; Zhang, Z.; Kong, G.; Li, P.; et al. Evaluation of circulating small extracellular vesicles derived miRNAs as biomarkers of early colon cancer: A comparison with plasma total miRNAs. J. Extracell. Vesicles 2019, 8, 1643670. [CrossRef] [PubMed]

16. Xiao, Y.; Zhong, J.; Zhong, B.; Huang, J.; Jiang, L.; Jiang, Y.; Yuan, J.; Sun, J.; Dai, L.; Yang, C.; et al. Exosomes as potential sources of biomarkers in colorectal cancer. Cancer Lett. 2020, 476, 13-22. [CrossRef]

17. Liu, W.; Yang, D.; Chen, L.; Liu, Q.; Wang, W.; Yang, Z.; Shang, A.; Quan, W.; Li, D. Plasma Exosomal miRNA-139-3p is a Novel Biomarker of Colorectal Cancer. J. Cancer 2020, 11, 4899-4906. [CrossRef]

18. Francavilla, A.; Turoczi, S.; Tarallo, S.; Vodicka, P.; Pardini, B.; Naccarati, A. Exosomal microRNAs and other non-coding RNAs as colorectal cancer biomarkers: A review. Mutagenesis 2020, 35, 243-260. [CrossRef]

19. Egloff, S.; Melnychuk, N.; Reisch, A.; Martin, S.; Klymchenko, A.S. Enzyme-free amplified detection of cellular microRNA by light-harvesting fluorescent nanoparticle probes. Biosens. Bioelectron. 2021, 179, 113084. [CrossRef]

20. Pang, S.-W.; Awi, N.J.; Armon, S.; Lim, W.W.-D.; Low, J.S.-H.; Peh, K.-B.; Peh, S.-C.; Teow, S.-Y. Current update of laboratory molecular diagnostics advancement in management of colorectal cancer (CRC). Diagnostics 2020, 10, 9. [CrossRef]

21. Gootenberg, J.S.; Abudayyeh, O.O.; Lee, J.W.; Ezzletzbichler, P.; Dy, A.J.; Joung, J.; Verdine, V.; Donghia, N.; Daringer, N.M.; Freije, C.A.; et al. Nucleic acid detection with CRISPR-Cas13a/C2c2. Science 2017, 356, 241-250. [CrossRef] [PubMed]

22. Gootenberg, J.S.; Abudayyeh, O.O.; Kellner, M.J.; Joung, J.; Collins, J.J.; Zhang, F. Multiplexed and portable nucleic acid detection platform with Cas13, Cas12a and Csm6. Science 2018, 360, 439-444. [CrossRef] [PubMed]

23. Chertow, D.S. CRISPR Portable Diagnostic Tools. Science 2018, 360, 381-383. [CrossRef] [PubMed]

24. Kellner, M.J.; Koob, J.G.; Gootenberg, J.S.; Abudayyeh, O.O.; Zhang, F. SHERLOCK: Nucleic acid detection with CRISPR nucleases. Nat. Prot. 2019, 14, 2986-3012. [CrossRef]

25. Li, L.; Li, S.; Wu, N.; Wu, J.; Wang, G.; Zhao, G.; Wang, J. HOLMESv2: A CRISPR-Cas12b-Assisted Platform for Nucleic Acid Detection and DNA Methylation Quantitation. ACS Synth. Biol. 2019, 8, 2228-2237. [CrossRef] [PubMed]

26. Myhrvold, C.; Freije, C.A.; Gootenberg, J.S.; Abudayyeh, O.O.; Metsky, H.C.; Durbin, A.F.; Kellner, M.J.; Tan, A.L.; Paul, L.M.; Parham, L.A.; et al. Field-deployable viral diagnostics using CRISPR-Cas13. Science 2018, 360, 444-448. [CrossRef]

27. Bruch, R.; Urban, G.A.; Dincer, C. CRISPR/Cas Powered Multiplexed Biosensing. Trends Biotechnol. 2019, 37, 791-792. [CrossRef]

28. Zuo, X.; Fan, C.; Chen, H.Y. Biosensing: CRISPR-powered diagnostics. Nat. Biomed. Eng. 2017, 1, 0091. [CrossRef]

29. Li, Y.; Li, S.; Wang, J.; Liu, G. CRISPR/Cas Systems towards Next-Generation Biosensing. Trends Biotechnol. 2019, 37, 730-743. [CrossRef] 
30. Burmistrz, M.; Krakowski, K.; Krawczyk-Balska, A. RNA-targeting CRISPR-Cas systems and their applications. Int. J. Mol. 2020, 21, 1122. [CrossRef]

31. Chen, J.S.; Ma, E.; Harrington, L.B.; Da Costa, M.; Tian, X.; Palefsky, J.M.; Doudna, J.A. CRISPR-Cas12a target binding unleashes indiscriminate single-stranded DNase activity. Science 2018, 360, 436-439. [CrossRef]

32. Mukama, O.; Wu, J.; Li, Z.; Liang, Q.; Yi, Z.; Lu, X.; Liu, Y.; Liu, Y.; Hussain, M.; Makafe, G.G.; et al. An ultrasensitive and specific point-of-care CRISPR/Cas12 based lateral flow biosensor for the rapid detection of nucleic acids. Biosens. Bioelectron. 2020, 10, 112143. [CrossRef]

33. Wong, S.H.; Yu, J. Gut microbiota in colorectal cancer: Mechanisms of action and clinical applications. Nat. Rev. Gastroenterol. Hepatol. 2019, 16, 690-704. [CrossRef]

34. Brenner, H.; Chen, C. The colorectal cancer epidemic: Challenges and opportunities for primary, secondary and tertiary prevention. Br. J. Cancer 2018, 119, 785-792. [CrossRef]

35. International Agency for Research on Cancer (IARC). Globocan 2020. Available online: https://gco.iarc.fr/today/home (accessed on 14 July 2021).

36. Nguyen, H.T.; Duong, H.Q. The molecular characteristics of colorectal cancer: Implications for diagnosis and therapy (review). Oncol. Lett. 2018, 16, 9-18. [CrossRef]

37. Czene, K.; Lichtenstein, P.; Hemminki, K. Environmental and heritable causes of cancer among 9.6 million individuals in the Swedish Family-Cancer Database. Int. J. Cancer 2002, 99, 260-266. [CrossRef]

38. Lichtenstein, P.; Holm, N.V.; Verkasalo, P.K.; Iliadou, A.; Kaprio, J.; Koskenvou, M.; Pukkala, E.; Skytthe, A.; Hermminki, K. Environmental and heritable factors in the causation of cancer-Analyses of cohorts of twins from Sweden, Denmark, and Finland. N. Engl. J. Med. 2000, 343, 78-85. [CrossRef] [PubMed]

39. Keum, N.N.; Giovannucci, E. Global burden of colorectal cancer: Emerging trends, risk factors and prevention strategies. Nat. Rev. Gastroenterol. Hepatol. 2019, 16, 713-732. [CrossRef] [PubMed]

40. Fleming, M.; Ravula, S.; Tatishchev, S.F.; Wang, H.L. Colorectal carcinoma: Pathologic aspects. J. Gastrointest. Oncol. 2012, 3, 153-173. [PubMed]

41. Amin, M.B.; Edge, S.B.; Greene, F.L.; Byrd, D.R.; Brookland, R.K.; Washington, M.K.; Gershenwald, J.E.; Compton, C.C.; Hess, K.R.; Sullivan, D.C.; et al. AJCC Cancer Staging Manual, 8th ed.; Springer International Publishing; American Joint Commission on Cancer: Chicago, IL, USA, 2017; pp. 251-274.

42. National Cancer Institute: Diagnosis and Staging. Available online: https://www.cancer.gov/about-cancer/diagnosis-staging/ staging (accessed on 6 September 2021).

43. National Cancer Institute: Surveillance, Epidemiology, and End Results Program (SEER 2017)—Statistics at a Glance. Available online: https:/ / seer.cancer.gov/statfacts/html/colorect.html (accessed on 9 July 2021).

44. Idos, G.E.; Kwok, J.; Bonthala, N.; Kysh, L.; Gruber, S.B.; Qu, C. The Prognostic Implications of Tumor Infiltrating Lymphocytes in Colorectal Cancer: A Systematic Review and Meta-Analysis. Sci. Rep. 2020, 10, 3360. [CrossRef]

45. Das, V.; Kalita, J.; Pal, M. Predictive and prognostic biomarkers in colorectal cancer: A systematic review of recent advances and challenges. Biomed. Pharmacother. 2017, 87, 8-19. [CrossRef]

46. Boakye, D.; Rillmann, B.; Walter, V.; Jansen, L.; Hoffmeister, M.; Brenner, H. Impact of comorbidity and frailty on prognosis in colorectal cancer patients: A systematic review and meta-analysis. Cancer Treat. Rev. 2018, 64, 30-39. [CrossRef]

47. White, A.; Ironmonger, L.; Steele, R.J.C.; Ormiston-Smith, N.; Crawford, C.; Seims, A. A review of sex-related differences in colorectal cancer incidence, screening uptake, routes to diagnosis, cancer stage and survival in the UK. BMC Cancer 2018, 18, 906. [CrossRef]

48. Brouwer, N.P.M.; Bos, A.C.R.K.; Lemmens, V.E.P.P.; Tanis, P.J.; Hugen, N.; Nagtegaal, I.D.; de Wilt, J.H.W.; Verhoeven, R.H.A. An overview of 25 years of incidence, treatment and outcome of colorectal cancer patients. Int. J. Cancer 2018, 143, $2758-2766$. [CrossRef]

49. Marcuello, M.; Vymetalkova, V.; Neves, R.P.L.; Duran-Sanchon, S.; Vedeld, H.M.; Tham, E.; van Dalum, G.; Flügen, G.; GarciaBarberan, V.; Fijneman, R.J.; et al. Circu-lating biomarkers for early detection and clinical management of colorectal cancer. Mol. Asp. Med. 2019, 69, 107-122. [CrossRef] [PubMed]

50. American Cancer Socierty, Colorectal Cancer-Early Detection, Diagnosis and Staging. Available online: https://www.cancer.org/ cancer/colon-rectal-cancer/detection-diagnosis-staging/detection.html (accessed on 14 July 2021).

51. Wang, Y.W.; Chen, H.H.; Wu, M.S.; Chiu, H.M. Current status and future challenge of population-based organized colorectal cancer screening: Lesson from the first decade of Taiwanese program. J. Formos. Med. Assoc. 2018, 117, 358-364. [CrossRef]

52. Robertson, D.J.; Ladabaum, U. Opportunities and Challenges in Moving from Current Guidelines to Personalized Colorectal Cancer Screening. Gastroenterology 2019, 156, 904-917. [CrossRef] [PubMed]

53. Gan, X.; Wang, T.; Chen, Z.Y.; Zhang, K.H. Blood-derived molecular signatures as biomarker panels for the early detection of colorectal cancer. Mol. Biol. Rep. 2020, 47, 8159-8168. [CrossRef]

54. Lurvink, R.J.; Tajzai, R.; Rovers, K.P.; Wassenaar, E.C.E.; Moes, D.J.A.R.; Pluimakers, G.; Boerma, D.; Burger, J.W.A.; Nienhuijs, S.W.; de Hingh, I.H.J.T.; et al. Systemic Pharmacokinetics of Oxaliplatin After Intraperitoneal Admin-istration by Electrostatic Pressurized Intraperitoneal Aerosol Chemotherapy (ePIPAC) in Patients with Unresectable Colorectal Peritoneal Metastases in the CRC-PIPAC Trial. Ann. Surg. Oncol. 2021, 28, 265-272. [CrossRef] [PubMed] 
55. Petrelli, F.; Comito, T.; Barni, S.; Pancera, G.; Scorsetti, M.; Ghidini, A. Stereotactic body radiotherapy for colorectal cancer liver metastases: A systematic review. Radiother. Oncol. 2018, 129, 427-434. [CrossRef] [PubMed]

56. Ganesh, K.; Stadler, Z.K.; Cercek, A.; Mendelsohn, R.B.; Shia, J.; Segal, N.H.; Diaz, L.A. Immunotherapy in colorectal cancer: Rationale, challenges and potential. Nat. Rev. Gastroenterol. Hepatol. 2019, 16, 361-375. [CrossRef] [PubMed]

57. Oliveres, H.; Pesántez, D.; Maurel, J. Lessons to learn for adequate targeted therapy development in metastatic colorectal cancer patients. Int. J. Mol. Sci. 2021, 22, 5019. [CrossRef] [PubMed]

58. Tiwari, A.; Saraf, S.; Jain, A.; Panda, P.K.; Verma, A.; Jain, S.K. Basics to advances in nanotherapy of colorectal cancer. Drug Deliv. Transl. Res. 2020, 10, 319-338. [CrossRef]

59. Molinari, C.; Marisi, G.; Passardi, A.; Matteucci, L.; De Maio, G.; Ulivi, P. Heterogeneity in colorectal cancer: A challenge for personalized medicine? Int. J. Mol. Sci. 2018, 19, 3733. [CrossRef] [PubMed]

60. Mahasneh, A.; Al-Shaheri, F.; Jamal, E. Molecular biomarkers for an early diagnosis, effective treatment and prognosis of colorectal cancer: Current updates. Exp. Mol. Pathol. 2017, 102, 475-483. [CrossRef]

61. Loktionov, A. Biomarkers for detecting colorectal cancer non-invasively: DNA, RNA or proteins. World J. Gastrointest. Oncol. 2020, 12, 124-148. [CrossRef] [PubMed]

62. Moghimi-Dehkordi, B.; Safaee, A. An overview of colorectal cancer survival rates and prognosis in Asia. World J. Gastrointest. Oncol. 2020, 4, 71-75. [CrossRef]

63. Simon, K. Colorectal cancer development and advances in screening. Clin. Interv. Aging 2016, 11, 967-976.

64. Nikolouzakis, T.K.; Vassilopoulou, L.; Fragkiadaki, P.; Sapsakos, T.M.; Papadakis, G.Z.; Spandidos, D.A.; Tsatsakis, A.M.; Tsiaoussis, J. Improving diagnosis, prognosis and prediction by using biomarkers in CRC patients (Review). Oncol. Rep. 2018, 39, 2455-2472. [CrossRef]

65. Guinney, J.; Dienstmann, R.; Wang, X.; De Reyniès, A.; Schlicker, A.; Soneson, C.; Marisa, L.; Roepman, P.; Nyamundanda, G.; Angelino, P.; et al. The consensus molecular subtypes of colorectal cancer. Nat. Med. 2015, 21, 1350-1356. [CrossRef]

66. Martini, G.; Dienstmann, R.; Ros, J.; Baraibar, I.; Cuadra-Urteaga, J.L.; Salva, F.; Ciardiello, D.; Mulet, N.; Argiles, G.; Tab-ernero, J.; et al. Molecular subtypes and the evolution of treatment management in metastatic colorectal cancer. Ther. Adv. Med. Oncol. 2020, 12, 1758835920936089. [CrossRef]

67. Amaro, A.; Chiara, S.; Pfeffer, U. Molecular Evolution of Colorectal Cancer: From Multistep Carcinogenesis to the Big Bang. Cancer Metastasis Rev. 2016, 35, 63-74. [CrossRef] [PubMed]

68. Kreso, A.; O’Brien, C.A.; van Galen, P.; Gan, O.I.; Notta, F.; Brown, A.M.; Ng, K.; Ma, J.; Wienholds, E.; Dunant, C.; et al. Variable Clonal Repopulation Dynamics Influence Chemotherapy Response in Colorectal Cancer. Science 2013, 339, 543-548. [CrossRef] [PubMed]

69. Stintzing, S.; Tejpar, S.; Gibbs, P.; Thiebach, L.; Lenz, H.J. Understanding the Role of Primary Tumour Localisation in Colorectal Cancer Treatment and Outcomes. Eur. J. Cancer 2017, 84, 69-80. [CrossRef]

70. Zhai, Z.; Yu, X.; Yang, B.; Zhang, Y.; Zhang, L.; Li, X.; Sun, H. Colorectal cancer heterogeneity and targeted therapy: Clinical implications, challenges and solutions for treatment resistance. Semin. Cell Dev. Biol. 2017, 64, 107-115. [CrossRef] [PubMed]

71. Issa, I.A.; NouredDine, M. Colorectal cancer screening: An updated review of the available options. World J. Gastrointest. Oncol. 2017, 23, 5086-5096. [CrossRef] [PubMed]

72. Kavousipour, S.; Khademi, F.; Zamani, M.; Vakili, B.; Mokarram, P. Novel biotechnology approaches in colorectal cancer diagnosis and therapy. Biotechnol. Lett. 2017, 39, 785-803. [CrossRef] [PubMed]

73. Guo, F.; De Brabander, I.; Francart, J.; Candeur, M.; Polus, M.; Van Eycken, L.; Brenner, H. Benefits of switching from guai-acbased faecal occult blood to faecal immunochemical testing: Experience from the Wallonia-Brussels colorectal cancer screening programme. Br. J. Cancer 2020, 122, 1109-1117. [CrossRef]

74. Carethers, J.M. Fecal DNA Testing for Colorectal Cancer Screening. Annu. Rev. Med. 2020, 71, 59-69. [CrossRef]

75. Rex, D.K.; Boland, C.R.; Dominitz, J.A.; Giardiello, F.M.; Johnson, D.A.; Kaltenbach, T.; Levin, T.R.; Lieberman, D.; Robertson, D.J. Colorectal Cancer Screening: Recommendations for Physicians and Patients from the U.S. Multi-Society Task Force on Colorectal Cancer. Gastroenterology 2017, 153, 307-323. [CrossRef]

76. Robbins, E.C.; Cross, A.J. Guaiac Fecal Occult Blood Tests and Mortality: A 30-Year Follow-up of Two Pooled Trials. Clin. Gastroenterol. Hepatol. 2021, 19, 892-894. [CrossRef]

77. Pickhardt, P.J.; Graffy, P.M.; Weigman, B.; Deiss-Yehiely, N.; Hassan, C.; Weiss, J.M. Diagnostic performance of multitarget stool DNA and CT colonography for noninvasive colorectal cancer screening. Radiology 2020, 297, 120-129. [CrossRef]

78. Lin, Z.; Chen, Y.; Lin, Y.; Lin, H.; Li, H.; Su, X.; Fang, Z.; Wang, J.; Wei, Q.; Teng, J.; et al. Potential miRNA biomarkers for the diagnosis and prognosis of esophageal cancer detected by a novel absolute quantitative RT-qPCR method. Sci. Rep. 2020, 10, 20065. [CrossRef]

79. Ilie, M.; Butori, C.; Lassalle, S.; Heeke, S.; Piton, N.; Sabourin, J.C.; Tanga, V.; Washetine, K.; Long-Mira, E.; Maitre, P.; et al. Optimization of EGFR mutation detection by the fully-automated qPCR-based Idylla system on tumor tissue from patients with non-small cell lung cancer. Oncotarget 2017, 8, 103055-103062. [CrossRef]

80. Rochow, H.; Franz, A.; Jung, M.; Weickmann, S.; Ralla, B.; Kilic, E.; Stephan, C.; Fendler, A.; Jung, K. Instability of circular RNAs in clinical tissue samples impairs their reliable expression analysis using RT-qPCR: From the myth of their advantage as biomarkers to reality. Theranostics 2020, 10, 9268-9279. [CrossRef] [PubMed] 
81. Vanova, B.; Kalman, M.; Jasek, K.; Kasubova, I.; Burjanivova, T.; Farkasova, A.; Kruzliak, P.; Busselberg, D.; Plank, L.; Lasabova, Z. Droplet digital PCR revealed high concordance between primary tumors and lymph node metastases in multiplex screening of KRAS mutations in colorectal cancer. Clin. Exp. Med. 2019, 19, 219-224. [CrossRef] [PubMed]

82. Tavano, F.; Gioffreda, D.; Valvano, M.R.; Palmieri, O.; Tardio, M.; Latiano, T.P.; Piepoli, A.; Maiello, E.; Pirozzi, F.; Andriulli, A. Droplet digital PCR quantification of miR-1290 as a circulating biomarker for pancreatic cancer. Sci. Rep. 2018, 8, 16389. [CrossRef] [PubMed]

83. Galbiati, S.; Damin, F.; Ferraro, L.; Soriani, N.; Burgio, V.; Ronzoni, M.; Gianni, L.; Ferrari, M.; Chiari, M. Microarray Approach Combined with ddPCR: An Useful Pipeline for the Detection and Quantification of Circulating Tumour dna Mutations. Cells 2019, 8, 769. [CrossRef]

84. Del Vecchio, F.; Mastroiaco, V.; Di Marco, A.; Compagnoni, C.; Capece, D.; Zazzeroni, F.; Capalbo, C.; Alesse, E.; Tessitore, A. Next-generation sequencing: Recent applications to the analysis of colorectal cancer. J. Transl. Med. 2017, 15, 246. [CrossRef] [PubMed]

85. Wang, M.; Zhang, R.; Li, J. CRISPR/cas systems redefine nucleic acid detection: Principles and methods. Biosens. Bioelectron. 2020, 165, 112430. [CrossRef]

86. Cheng, Y.; Dong, L.; Zhang, J.; Zhao, Y.; Li, Z. Recent advances in microRNA detection. Analyst 2018, 143, 1758-1774. [CrossRef] [PubMed]

87. Chen, J.; Fan, T.; Chen, Y.; Ye, L.; Zhang, C.; Liu, F.; Qin, Y.; Tan, Y.; Jiang, Y. Zeptomolar-level one-pot simultaneous detection of multiple colorectal cancer microRNAs by cascade isothermal amplification. Biosens. Bioelectron. 2020, 169, 112631. [CrossRef]

88. Bonini, A.; Poma, N.; Vivaldi, F.; Kirchhain, A.; Salvo, P.; Bottai, D.; Tavanti, A.; Di Francesco, F. Advances in biosensing: The CRISPR/Cas system as a new powerful tool for the detection of nucleic acids. J. Pharm. Biomed. Anal. 2021, 192, 113645. [CrossRef]

89. Latacz, M.; Snarska, J.; Kostyra, E.; Wroński, K.; Fiedorowicz, E.; Savelkoul, H.; Jarmołowska, B.; Płomiński, J.; Grzybowski, R.; Cieślińska, A. CYP27B1 Gene Polymorphism rs10877012 in Patients Diagnosed with Colorectal Cancer. Nutrients 2020, 12, 998. [CrossRef] [PubMed]

90. Zwaenepoel, K.; Holmgaard Duelund, J.; De Winne, K.; Maes, V.; Weyn, C.; Lambin, S.; Dendooven, R.; Broeckx, G.; Steiniche, T.; Pauwels, P. Clinical Performance of the Idylla MSI Test for a Rapid Assessment of the DNA Microsatellite Status in Human Colorectal Cancer. J. Mol. Diagn. 2020, 22, 386-395. [CrossRef] [PubMed]

91. Warren, J.D.; Xiong, W.; Bunker, A.M.; Vaughn, C.P.; Furtado, L.V.; Roberts, W.L.; Fang, J.C.; Samowitz, W.S.; Heichman, K.A. Septin 9 methylated DNA is a sensitive and specific blood test for colorectal cancer. BMC Med. 2011, 9, 133. [CrossRef] [PubMed]

92. Hao, Y.X.; Fu, Q.; Guo, Y.Y.; Ye, M.; Zhao, H.X.; Wang, Q.; Peng, X.M.; Li, Q.W.; Wang, R.L.; Xiao, W.H. Effectiveness of circulating tumor DNA for detection of KRAS gene mutations in colorectal cancer patients: A meta-analysis. OncoTargets Ther. 2017, 10, 945-953. [CrossRef]

93. Loupakis, F.; Moretto, R.; Aprile, G.; Muntoni, M.; Cremolini, C.; Iacono, D.; Casagrande, M.; Ferrari, L.; Salvatore, L.; Schirripa, M.; et al. Clinico-pathological nomogram for predicting BRAF mutational status of metastatic colorectal cancer. Br. J. Cancer 2016, 114, 30-36. [CrossRef]

94. Sepulveda, A.R.; Hamilton, S.R.; Allegra, C.J.; Grody, W.; Cushman-Vokoun, A.M.; Funkhouser, W.K.; Kopetz, S.E.; Lieu, C.; Lindor, N.M.; Minsky, B.D.; et al. Molecular biomarkers for the evaluation of colorectal cancer: Guideline from The American Society for Clinical Pathology, College of American Pathologists, Association for Molecular Pathology, and the American Society of Clinical Oncology. Am. J. Clin. Oncol. 2017, 35, 1453-1496. [CrossRef]

95. Ho, H.-H.; Joo, Y.-E. Novel biomarkers for the diagnosis and prognosis of colorectal cancer. Intest. Res. 2019, 18, 168-183.

96. Cha, B.S.; Park, K.S.; Park, J.S. Signature mRNA markers in extracellular vesicles for the accurate diagnosis of colorectal cancer. J. Biol. Eng. 2020, 14, 4. [CrossRef]

97. Kim, M.; Lee, S.T.; Choi, S.; Lee, H.; Kwon, S.S.; Byun, J.H.; Kim, Y.A.; Rhee, K.J.; Choi, J.R.; Kim, T.I.; et al. Fusobacterium nucleatum in biopsied tissues from colorectal cancer patients and alcohol consumption in Korea. Sci. Rep. 2020, $10,19915$. [CrossRef]

98. Shang, A.; Gu, C.; Wang, W.; Wang, X.; Sun, J.; Zeng, B.; Chen, C.; Chang, W.; Ping, Y.; Ji, P.; et al. Exosomal circPACRGL promotes progression of colorectal cancer via the miR-142-3p/miR-506-3p-TGF- $\beta 1$ axis. Mol. Cancer 2020, 19, 117. [CrossRef] [PubMed]

99. Kalra, H.; Drummen, G.P.; Mathivanan, S. Focus on extracellular vesicles: Introducing the next small big thing. Int. J. Mol. Sci. 2016, 17, 170. [CrossRef] [PubMed]

100. Kalishwaralal, K.; Kwon, W.Y.; Park, K.S. Exosomes for non-invasive Cancer monitoring. Biotechnol. J. 2019, 14, 1800430. [CrossRef] [PubMed]

101. Xiao, Y.; Li, Y.; Yuan, Y.; Liu, B.; Pan, S.; Liu, Q.; Qi, X.; Zhou, H.; Dong, W.; Jie, L. The potential of exosomes derived from colorectal cancer as a biomarker. Clin. Chim. Acta 2019, 490, 186-193. [CrossRef]

102. Koncina, E.; Haan, S.; Rauh, S.; Letellier, E. Prognostic and predictive molecular biomarkers for colorectal cancer: Updates and challenges. Cancers 2020, 12, 319. [CrossRef] [PubMed]

103. Vacante, M.; Borzì, A.M.; Basile, F.; Biondi, A. Biomarkers in colorectal cancer: Current clinical utility and future perspectives. World J. Clin. Cases 2019, 6, 869-881. [CrossRef]

104. Hu, T.; Wolfram, J.; Srivastava, S. Extracellular Vesicles in Cancer Detection: Hopes and Hypes. Trends Cancer 2021, 7, 122-133. [CrossRef] 
105. Vader, P.; Breakefield, X.O.; Wood, M.J.A. Extracellular vesicles: Emerging targets for cancer therapy. Trends Mol. Med. 2014, 20, 385-393. [CrossRef]

106. Xavier, C.P.R.; Caires, H.R.; Barbosa, M.A.G.; Bergantim, R.; Guimarães, J.E.; Vasconcelos, M.H. The Role of Extracellular Vesicles in the Hallmarks of Cancer and Drug Resistance. Cells 2020, 9, 1141. [CrossRef] [PubMed]

107. Vasconcelos, M.H.; Caires, H.R.; Abols, A.; Xavier, C.P.R.; Line, A. Extracellular vesicles as a novel source of biomarkers in liquid biopsies for monitoring cancer progression and drug resistance. Drug Resist. Updat. 2019, 47, 100647. [CrossRef] [PubMed]

108. Choudhry, H.; Harris, A.L. Advances in Hypoxia-Inducible Factor Biology. Cell Metab. 2018, 27, 281-298. [CrossRef]

109. Wei, Y.; Wang, D.; Jin, F.; Bian, Z.; Li, L.; Liang, H.; Li, M.; Shi, L.; Pan, C.; Zhu, D.; et al. Pyruvate kinase type M2 promotes tumour cell exosome release via phosphorylating synaptosome-associated protein 23. Nat. Commun. 2017, 8, 14041. [CrossRef] [PubMed]

110. Ji, Q.; Zhou, L.; Sui, H.; Yang, L.; Wu, X.; Song, Q.; Jia, R.; Li, R.; Sun, J.; Wang, Z.; et al. Primary tumors release ITGBL1-rich extracellular vesicles to promote distal metastatic tumor growth through fibroblast-niche formation. Nat. Commun. 2020, 11, 1211. [CrossRef] [PubMed]

111. Palazzolo, S.; Memeo, L.; Hadla, M.; Duzagac, F.; Steffan, A.; Perin, T.; Canzonieri, V.; Tuccinardi, T.; Caligiuri, I.; Rizzolio, F. Cancer extracellular vesicles: Next-generation diagnostic and drug delivery nanotools. Cancers 2020, 12, 3165. [CrossRef] [PubMed]

112. Bracci, L.; Lozupone, F.; Parolini, I. The role of exosomes in colorectal cancer disease progression and response to therapy. Cytokine Growth Factor Rev. 2020, 51, 84-91. [CrossRef]

113. Bahrami, A.; Moradi Binabaj, M.; Ferns, G.A. Exosomes: Emerging modulators of signal transduction in colorectal cancer from molecular understanding to clinical application. Biomed. Pharmacother. 2021, 141, 111882. [CrossRef]

114. Cheshomi, H.; Matin, M.M. Exosomes and their importance in metastasis, diagnosis, and therapy of colorectal cancer. J. Cell. Biochem. 2019, 120, 2671-2686. [CrossRef] [PubMed]

115. Vafaei, S.; Roudi, R.; Madjd, Z.; Aref, A.R.; Ebrahimi, M. Potential theranostics of circulating tumor cells and tumor-derived exosomes application in colorectal cancer. Cancer Cell Int. 2020, 20, 288. [CrossRef]

116. Bebelman, M.P.; Smit, M.J.; Pegtel, D.M.; Baglio, S.R. Biogenesis and function of extracellular vesicles in cancer. Pharmacol. Ther. 2018, 188, 1-11. [CrossRef] [PubMed]

117. Bebelman, M.P.; Janssen, E.; Pegtel, D.M.; Crudden, C. The forces driving cancer extracellular vesicle secretion. Neoplasia 2021, 23, 149-157. [CrossRef] [PubMed]

118. Fan, S.; Kroeger, B.; Marie, P.P.; Bridges, E.M.; Mason, J.D.; McCormick, K.; Zois, C.E.; Sheldon, H.; Khalid Alham, N.; Johnson, E.; et al. Glutamine deprivation alters the origin and function of cancer cell exosomes. EMBO J. 2020, 39 , e103009. [CrossRef] [PubMed]

119. Pegtel, D.M.; Gould, S.J. Exosomes. Annu. Rev. Biochem. 2019, 88, 487-514. [CrossRef]

120. Acuña, R.A.; Varas-Godoy, M.; Retamal, M.A. Connexin-46 Contained in Extracellular Vesicles Enhance Malignance Characteristics in Breast Cancer Cells. Biomolecules 2020, 10, 676. [CrossRef]

121. Mostafazadeh, M.; Samadi, N.; Kahroba, H.; Baradaran, B.; Haiaty, S.; Nouri, M. Potential roles and prognostic significance of exosomes in cancer drug resistance. Cell Biosci. 2021, 11, 1. [CrossRef]

122. Drula, R.; Ott, L.F.; Berindan-Neagoe, I.; Pantel, K.; Calin, G.A. Micrornas from liquid biopsy derived extracellular vesicles: Recent advances in detection and characterization methods. Cancers 2020, 12, 2009. [CrossRef]

123. Han, W.; Cui, H.; Liang, J.; Su, X. Role of MicroRNA-30c in cancer progression. J. Cancer 2020, 11, 2593-2601. [CrossRef]

124. Noguchi, T.; Toiyama, Y.; Kitajima, T.; Imaoka, H.; Hiro, J.; Saigusa, S.; Tanaka, K.; Inoue, Y.; Mohri, Y.; Toden, S.; et al. MiRNA-503 Promotes Tumor Progression and Is Associated with Early Recurrence and Poor Prognosis in Human Colorectal Cancer. Oncology 2016, 90, 221-231. [CrossRef]

125. Yi, M.; Xu, L.; Jiao, Y.; Luo, S.; Li, A.; Wu, K. The role of cancer-derived microRNAs in cancer immune escape. J. Hematol. Oncol. 2020, 13, 25. [CrossRef]

126. Wang, S.; Zhang, Z.; Gao, Q. Transfer of microRNA-25 by colorectal cancer cell-derived extracellular vesicles facilitates colo-rectal cancer development and metastasis. Mol. Ther. Nucleic Acids 2021, 23, 552-564. [CrossRef] [PubMed]

127. Jiang, L.; Zhang, Y.; Li, B.; Kang, M.; Yang, Z.; Lin, C.; Hu, K.; Wei, Z.; Xu, M.; Mi, J.; et al. miRNAs derived from circulating small extracellular vesicles as diagnostic biomarkers for nasopharyngeal carcinoma. Cancer Sci. 2021, 112, 2393-2404. [CrossRef]

128. Gallardo-Gómez, M.; Álvarez-Chaver, P.; Cubiella, J. Colorectal cancer screening and diagnosis: Omics-based technologies for development of a non-invasive blood-based method. Expert Rev. Anticancer Ther. 2021, 21, 723-738. [CrossRef]

129. Danese, E.; Minicozzi, A.M.; Benati, M.; Paviati, E.; Lima-Oliveira, G.; Gusella, M.; Pasini, F.; Salvagno, G.L.; Montagnana, M.; Lippi, G. Reference miRNAs for colorectal cancer: Analysis and verification of current data. Sci. Rep. 2017, 7, 8413. [CrossRef]

130. Nassar, F.J.; Msheik, Z.S.; Itani, M.M.; Helou, R.E.; Hadla, R.; Kreidieh, F.; Bejjany, R.; Mukherji, D.; Shamseddine, A.; Nasr, R.R.; et al. Circulating miRNA as Biomarkers for Colorectal Cancer Diagnosis and Liver Metastasis. Diagnostics 2021, 11, 341. [CrossRef]

131. Yan, S.; Han, B.; Gao, S.; Wang, X.; Wang, Z.; Wang, F.; Zhang, J.; Xu, D.; Sun, B. Exosome-encapsulated microRNAs as circulating biomarkers for colorectal cancer. Oncotarget 2017, 8, 60149-60158. [CrossRef] 
132. de Miguel Pérez, D.; Rodriguez Martínez, A.; Ortigosa Palomo, A.; Delgado Ureña, M.; Garcia Puche, J.L.; Robles Remacho, A.; Exposito Hernandez, J.; Lorente Acosta, J.A.; Ortega Sánchez, F.G.; Serrano, M.J. Extracellular vesicle-miRNAs as liquid biopsy biomarkers for disease identification and prognosis in metastatic colorectal cancer patients. Sci. Rep. 2020, 10, 3974. [CrossRef]

133. Zhang, N.; Zhang, P.P.; Huang, J.J.; Wang, Z.Y.; Zhang, Z.H.; Yuan, J.Z.; Ma, E.M.; Liu, X.; Bai, J. Reduced serum exosomal miR-874 expression predicts poor prognosis in colorectal cancer. Eur. Rev. Med. Pharmacol. Sci. 2020, 24, 664-672.

134. Köberle, V.; Pleli, T.; Schmithals, C.; Augusto Alonso, E.; Haupenthal, J.; Bönig, H.; Peveling-Oberhag, J.; Biondi, R.M.; Zeuzem, S.; Kronenberger, B.; et al. Differential Stability of Cell-Free Circulating microRNAs: Implications for Their Utilization as Biomarkers. PLoS ONE 2013, 8, e75184. [CrossRef]

135. Rahbarghazi, R.; Jabbari, N.; Sani, N.A.; Asghari, R.; Salimi, L.; Kalashani, S.A.; Feghhi, M.; Etemadi, T.; Akbariazar, E.; Mahmoudi, M.; et al. Tumor-derived extracellular vesicles: Reliable tools for Cancer diagnosis and clinical applications. Cell Commun. Signal. 2019, 17, 73. [CrossRef] [PubMed]

136. Shi, Y.; Zhuang, Y.; Zhang, J.; Chen, M.; Wu, S. Four circulating exosomal miRNAs as novel potential biomarkers for the early diagnosis of human colorectal cancer. Tissue Cell 2021, 70, 101499. [CrossRef] [PubMed]

137. Jin, G.; Liu, Y.; Zhang, J.; Bian, Z.; Yao, S.; Fei, B.; Zhou, L.; Yin, Y.; Huang, Z. A panel of serum exosomal microRNAs as predictive markers for chemoresistance in advanced colorectal cancer. Cancer Chemother. Pharmacol. 2019, 84, 315-325. [CrossRef] [PubMed]

138. Alves dos Santos, K.; Clemente dos Santos, I.C.; Santos Silva, C.; Gomes Ribeiro, H.; de Farias Domingos, I.; Nogueira Silbiger, V. Circulating Exosomal miRNAs as Biomarkers for the Diagnosis and Prognosis of Colorectal Cancer. Int. J. Mol. Sci. 2021, 22, 346. [CrossRef]

139. Zanutto, S.; Ciniselli, C.M.; Belfiore, A.; Lecchi, M.; Masci, E.; Delconte, G.; Primignani, M.; Tosetti, G.; Dal Fante, M.; Fazzini, L.; et al. Plasma miRNA-based signatures in CRC screening programs. Int. J. Cancer 2020, 146, 1164-1173. [CrossRef]

140. Fu, D.; Chen, Y.; Xu, D. Circulating miR-449a predicts survival outcome for colorectal cancer following curative resection: An observational study. Medicine 2021, 100, e25022. [CrossRef] [PubMed]

141. Pan, Z.; Miao, L. Serum microrna-592 serves as a novel potential biomarker for early diagnosis of colorectal cancer. Oncol. Lett. 2020, 20, 1119-1126. [CrossRef]

142. Cui, X.; Lv, Z.; Ding, H.; Xing, C.; Yuan, Y. MiR-1539 and Its Potential Role as a Novel Biomarker for Colorectal Cancer. Front. Oncol. 2021, 10, 3449. [CrossRef]

143. Maminezhad, H.; Ghanadian, S.; Pakravan, K.; Razmara, E.; Rouhollah, F.; Mossahebi-Mohammadi, M.; Babashah, S. A panel of six-circulating miRNA signature in serum and its potential diagnostic value in colorectal cancer. Life Sci. 2020, $258,118226$. [CrossRef]

144. Wang, N.; Liu, W. Increased expression of miR-552 acts as a potential predictor biomarker for poor prognosis of colorectal cancer. Eur. Rev. Med. Pharmacol. Sci. 2018, 22, 412-416.

145. Fiala, O.; Pitule, P.; Hosek, P.; Liska, V.; Sorejs, O.; Bruha, J.; Vycital, O.; Buchler, T.; Poprach, A.; Topolcan, O.; et al. The association of miR-126-3p, miR-126-5p and miR-664-3p expression profiles with outcomes of patients with metastatic colorectal cancer treated with bevacizumab. Tumor Biol. 2017, 39, 1010428317709283. [CrossRef]

146. Ulivi, P.; Canale, M.; Passardi, A.; Marisi, G.; Valgiusti, M.; Frassineti, G.L.; Calistri, D.; Amadori, D.; Scarpi, E. Circulating plasma levels of miR-20b, miR-29b and mir-155 as predictors of bevacizumab efficacy in patients with metastatic colorectal cancer. Int. J. Mol. Sci. 2018, 19, 307. [CrossRef] [PubMed]

147. Fu, F.; Jiang, W.; Zhou, L.; Chen, Z. Circulating Exosomal miR-17-5p and miR-92a-3p Predict Pathologic Stage and Grade of Colorectal Cancer. Transl. Oncol. 2018, 11, 221-232. [CrossRef]

148. Tang, Y.; Zhao, Y.; Song, X.; Song, X.; Niu, L.; Xie, L. Tumor-derived exosomal miRNA-320d as a biomarker for metastatic colorectal cancer. J. Clin. Lab. Anal. 2019, 33, e23004. [CrossRef] [PubMed]

149. miRBase: The microRNA Database. Available online: http://www.mirbase.org/ (accessed on 18 May 2021).

150. Kozomara, A.; Birgaoanu, M.; Griffiths-Jones, S. MiRBase: From microRNA sequences to function. Nucleic Acids Res. 2019, 47, 155-162. [CrossRef]

151. Gasparello, J.; Papi, C.; Allegretti, M.; Giordani, E.; Carboni, F.; Zazza, S.; Pescarmona, E.; Romania, P.; Giacomini, P.; Scapoli, C.; et al. A distinctive microrna (miRNA) signature in the blood of colorectal cancer (CRC) patients at sur-gery. Cancers 2020, 12, 2410. [CrossRef]

152. Ali Syeda, Z.; Langden, S.S.S.; Munkhzul, C.; Lee, M.; Song, S.J. Regulatory Mechanism of MicroRNA Expression in Cancer. Int. J. Mol. Sci. 2020, 21, 1723. [CrossRef] [PubMed]

153. Ferrari, A.; Neefs, I.; Hoeck, S.; Peeters, M.; Van Hal, G. Towards Novel Non-Invasive Colorectal Cancer Screening Methods: A Comprehensive Review. Cancers 2021, 13, 1820. [CrossRef]

154. Pinzani, P.; D’Argenio, V.; Del Re, M.; Pellegrini, C.; Cucchiara, F.; Salvianti, F.; Galbiati, S. Updates on liquid biopsy: Current trends and future perspectives for clinical application in solid tumors. Clin. Chem. Lab. Med. 2021, 59, 1181-1200. [CrossRef]

155. Sazanov, A.A.; Kiselyova, E.V.; Zakharenko, A.A.; Romanov, M.N.; Zaraysky, M.I. Plasma and saliva miR-21 expression in colorectal cancer patients. J. Appl. Genet. 2017, 58, 231-237. [CrossRef]

156. Rapado-González, Ó.; Majem, B.; Álvarez-Castro, A.; Díaz-Peña, R.; Abalo, A.; Suárez-Cabrera, L.; Gil-Moreno, A.; Santa-maría, A.; López-López, R.; Muinelo-Romay, L.; et al. A Novel Saliva-Based miRNA Signature for Colo-rectal Cancer Diagnosis. J. Clin. Med. 2019, 8, 2029. [CrossRef] 
157. Burstein, D.; Harrington, L.B.; Strutt, S.C.; Probst, A.J.; Anantharaman, K.; Thomas, B.C.; Doudna, J.A.; Banfield, J.F. New CRISPR-Cas systems from uncultivated microbes. Nature 2017, 542, 237-241. [CrossRef] [PubMed]

158. Koonin, E.V.; Makarova, K.S.; Zhang, F. Diversity, classification and evolution of CRISPR-Cas systems. Curr. Opin. Microbiol. 2017, 37, 67-78. [CrossRef] [PubMed]

159. Makarova, K.S.; Wolf, Y.I.; Iranzo, J.; Shmakov, S.A.; Alkhnbashi, O.S.; Brouns, S.J.J.; Charpentier, E.; Cheng, D.; Haft, D.H.; Horvath, P.; et al. Evolutionary classification of CRISPR-Cas systems: A burst of class 2 and derived variants. Nat. Rev. Microbiol. 2020, 18, 67-83. [CrossRef]

160. Makarova, K.S.; Wolf, Y.I.; Alkhnbashi, O.S.; Costa, F.; Shah, S.A.; Saunders, S.J.; Barrangou, R.; Brouns, S.J.J.; Charpentier, E.; Haft, D.H.; et al. An updated evolutionary classification of CRISPR-Cas systems. Nat. Rev. Microbiol. 2015, 13, 722-736. [CrossRef] [PubMed]

161. Hille, F.; Charpentier, E. CRISPR-cas: Biology, mechanisms and relevance. Philos. Trans. R. Soc. B 2016, 371, 20150496. [CrossRef]

162. Shiriaeva, A.; Fedorov, I.; Vyhovskyi, D.; Severinov, K. Detection of CRISPR adaptation. Biochem. Soc. Trans. 2020, 48, 257-269. [CrossRef]

163. McGinn, J.; Marraffini, L.A. Molecular mechanisms of CRISPR-Cas spacer acquisition. Nat. Rev. Microbiol. 2019, 17, 7-12. [CrossRef]

164. Mojica, F.J.M.; Díez-Villaseñor, C.; García-Martínez, J.; Almendros, C. Short motif sequences determine the targets of the prokaryotic CRISPR defence system. Microbiology 2009, 155, 733-740. [CrossRef]

165. Jinek, M.; Chylinski, K.; Fonfara, I.; Hauer, M.; Doudna, J.A.; Charpentier, E. A Programmable Dual-RNA-Guided DNA Endonuclease in Adaptive Bacterial Immunity. Science 2012, 337, 816-821. [CrossRef]

166. Didovik, A.; Bartłomiej, B.; Lev, T.; Hasty, J. Transcriptional Regulation with CRISPR-Cas9: Principles, Advances, and Applications. Curr. Opin. Biotechnol. 2016, 40, 177-184. [CrossRef]

167. Abid, H.Z.; Young, E.; McCaffrey, J.; Raseley, K.; Varapula, D.; Wang, H.Y.; Piazza, D.; Mell, J.; Xiao, M. Customized optical mapping by CRISPR-Cas9 mediated DNA labeling with multiple sgRNAs. Nucleic Acids Res. 2021, 49, e8. [CrossRef]

168. Wang, X.; Shang, X.; Huang, X. Next-generation pathogen diagnosis with CRISPR/Cas-based detection methods. Emerg. Microbes Infect. 2020, 9, 1682-1691. [CrossRef] [PubMed]

169. Annunziato, S.; Lutz, C.; Henneman, L.; Bhin, J.; Wong, K.; Siteur, B.; van Gerwen, B.; de Korte-Grimmerink, R.; Zafra, M.P.; Schatoff, E.M.; et al. In situ CRISPR-Cas9 base editing for the development of genetically engi-neered mouse models of breast cancer. EMBO J. 2020, 39, e102169. [CrossRef]

170. Liu, Z.; Liao, Z.; Chen, Y.; Zhou, L.; Huangting, W.; Xiao, H. Research on CRISPR/system in major cancers and its potential in cancer treatments. Clin. Transl. Oncol. 2021, 23, 425-433. [CrossRef]

171. Wang, W.; Song, F.; Feng, X.; Chu, X.; Dai, H.; Tian, J.; Fang, X.; Song, F.; Liu, B.; Li, L.; et al. Functional Interrogation of Enhancer Connectome Prioritizes Candidate Target Genes at Ovarian Cancer Susceptibility Loci. Front. Genet. 2021, $12,261$.

172. Li, J.; Yuan, S.; Norgard, R.J.; Yan, F.; Sun, Y.H.; Kim, I.K.; Merrell, A.J.; Sela, Y.; Jiang, Y.; Bhanu, N.V.; et al. Epigenetic and transcriptional control of the epidermal growth factor receptor regulates the tumor immune microenvironment in pancreatic cancer. Cancer Discov. 2021, 11, 736-753. [CrossRef] [PubMed]

173. Gao, Q.; Ouyang, W.; Kang, B.; Han, X.; Xiong, Y.; Ding, R.; Li, Y.; Wang, F.; Huang, L.; Chen, L.; et al. Selective targeting of the oncogenic KRAS G12S mutant allele by CRISPR/Cas9 induces efficient tumor regression. Theranostics 2020, 10, 5137-5153. [CrossRef]

174. Qiu, X.Y.; Zhu, L.Y.; Zhu, C.S.; Ma, J.X.; Hou, T.; Wu, X.M.; Xie, S.S.; Min, L.; Tan, D.A.; Zhang, D.Y.; et al. Highly Effective and Low-Cost MicroRNA Detection with CRISPR-Cas9. ACS Synth. Biol. 2018, 7, 807-813. [CrossRef]

175. Ledford, H. Landmark CRISPR trial shows promise against deadly disease. Nature 2021. [CrossRef]

176. Lim, G.B. Gene editing in patients with amyloidosis. Nat. Rev. Cardiol. 2021, 18, 611. [PubMed]

177. Gillmore, J.D.; Gane, E.; Taubel, J.; Kao, J.; Fontana, M.; Maitland, M.L.; Seitzer, J.; O'Connell, D.; Walsh, K.R.; Wood, K.; et al. CRISPR-Cas9 in vivo gene editing for transthyretin amyloidosis. N. Engl. J. Med. 2021, 385, 493-502. [CrossRef]

178. Aman, R.; Mahas, A.; Mahfouz, M. Nucleic Acid Detection Using CRISPR/Cas Biosensing Technologies. ACS Synth. Biol. 2020, 9 , 1226-1233. [CrossRef]

179. Shan, Y.; Zhou, X.; Huang, R.; Xing, D. High-Fidelity and Rapid Quantification of miRNA Combining crRNA Programmability and CRISPR/Cas13a trans-Cleavage Activity. Anal. Chem. 2019, 91, 5278-5285. [CrossRef]

180. Osborn, M.J.; Bhardwaj, A.; Bingea, S.P.; Knipping, F.; Feser, C.J.; Lees, C.J.; Collins, D.P.; Steer, C.J.; Blazar, B.R.; Tolar, J. CRISPR/Cas9-Based Lateral Flow and Fluorescence Diagnostics. Bioengineering 2021, 8, 23. [CrossRef] [PubMed]

181. Zhou, W.; Hu, L.; Ying, L.; Zhao, Z.; Chu, P.K.; Yu, X.F. A CRISPR-Cas9-triggered strand displacement amplification method for ultrasensitive DNA detection. Nat. Commun. 2018, 9, 5012. [CrossRef]

182. Bandaru, S.; Tsuji, M.H.; Shimizu, Y.; Usami, K.; Lee, S.; Takei, N.K.; Yoshitome, K.; Nishimura, Y.; Otsuki, T.; Ito, T. Structure-based design of gRNA for Cas13. Sci. Rep. 2020, 10, 11610. [CrossRef]

183. Wessels, H.H.; Méndez-Mancilla, A.; Guo, X.; Legut, M.; Daniloski, Z.; Sanjana, N.E. Massively parallel Cas13 screens reveal principles for guide RNA design. Nat. Biotechnol. 2020, 38, 722-727. [CrossRef]

184. Yan, W.X.; Chong, S.; Zhang, H.; Makarova, K.S.; Koonin, E.V.; Cheng, D.R.; Scott, D.A. Cas13d Is a Compact RNA-Targeting Type VI CRISPR Effector Positively Modulated by a WYL-Domain-Containing Accessory Protein. Mol. Cell 2018, 70, 327-339. [CrossRef] 
185. Patchsung, M.; Jantarug, K.; Pattama, A.; Aphicho, K.; Suraritdechachai, S.; Meesawat, P.; Sappakhaw, K.; Leelahakorn, N.; Ruenkam, T.; Wongsatit, T.; et al. Clinical validation of a Cas13-based assay for the detection of SARS-CoV-2 RNA. Nat. Biomed. Eng. 2020, 4, 1140-1149. [CrossRef] [PubMed]

186. Zhou, J.; Yin, L.; Dong, Y.; Peng, L.; Liu, G.; Man, S.; Ma, L. CRISPR-Cas13a based bacterial detection platform: Sensing pathogen Staphylococcus aureus in food samples. Anal. Chim. Acta 2020, 1127, 225-233. [CrossRef] [PubMed]

187. Baerwald, M.R.; Goodbla, A.M.; Nagarajan, R.P.; Gootenberg, J.S.; Abudayyeh, O.O.; Zhang, F.; Schreier, A.D. Rapid and accurate species identification for ecological studies and monitoring using CRISPR-based SHERLOCK. Mol. Ecol. Resour. 2020, 20, 961-970. [CrossRef]

188. Durán-Vinet, B.; Araya-Castro, K.; Chao, T.C.; Wood, S.A.; Gallardo, V.; Godoy, K.; Abanto, M. Potential applications of CRISPR/Cas for next-generation biomonitoring of harmful algae blooms: A review. Harmful Algae 2021, 103, 102027. [CrossRef]

189. Granados-Riveron, J.T.; Aquino-Jarquin, G. CRISPR/Cas13-Based Approaches for Ultrasensitive and Specific Detection of microRNAs. Cells 2021, 10, 1655. [CrossRef]

190. Pausch, P.; Al-Shayeb, B.; Bisom-Rapp, E.; Tsuchida, C.A.; Li, Z.; Cress, B.F.; Knott, G.J.; Jacobsen, S.E.; Banfield, J.F.; Doudna, J.A. CRISPR-Cas $\Phi$ from huge phages is a hypercompact genome editor. Science 2020, 369, 333-337. [CrossRef] [PubMed]

191. Vinchhi, P.; Patel, M.M. Triumph against cancer: Invading colorectal cancer with nanotechnology. Expert Opin. Drug Deliv. 2021, 18, 1169-1192. [CrossRef]

192. Ackerman, C.M.; Myhrvold, C.; Thakku, S.G.; Freije, C.A.; Metsky, H.C.; Yang, D.K.; Ye, S.H.; Boehm, C.K.; Kosoko-Thoroddsen, T.-S.F.; Kehe, J.; et al. Massively multiplexed nucleic acid detection using Cas13. Nature 2020, 582, 277-282. [CrossRef] [PubMed]

193. Shinoda, H.; Taguchi, Y.; Nakagawa, R.; Makino, A.; Okazaki, S.; Nakano, M.; Muramoto, Y.; Takahashi, C.; Takahashi, I.; Ando, J.; et al. Amplification-free RNA detection with CRISPR-Cas13. Commun. Biol. 2021, 4, 476. [CrossRef] [PubMed]

194. Sha, Y.; Huang, R.; Huang, M.; Yue, H.; Shan, Y.; Hu, J.; Xing, D. Cascade CRISPR/cas enables amplification-free microRNA sensing with $\mathrm{fM}$-sensitivity and single-base-specificity. Chem. Commun. 2021, 57, 247-250. [CrossRef]

195. Cui, Y.; Fan, S.; Yuan, Z.; Song, M.; Hu, J.; Qian, D.; Zhen, D.; Li, J.; Zhu, B. Ultrasensitive electrochemical assay for mi-croRNA-21 based on CRISPR/Cas13a-assisted catalytic hairpin assembly. Talanta 2021, 224, 121878. [CrossRef] [PubMed]

196. Bruch, R.; Baaske, J.; Chatelle, C.; Meirich, M.; Madlener, S.; Weber, W.; Dincer, C.; Urban, G.A. CRISPR/Cas13a-Powered Electrochemical Microfluidic Biosensor for Nucleic Acid Amplification-Free miRNA Diagnostics. Adv. Mater. 2019, 31, 1905311. [CrossRef]

197. Zhou, T.; Huang, R.; Huang, M.; Shen, J.; Shan, Y.; Xing, D. CRISPR/Cas13a Powered Portable Electrochemiluminescence Chip for Ultrasensitive and Specific MiRNA Detection. Adv. Sci. 2020, 7, 1903661. [CrossRef] [PubMed]

198. Wee, E.J.H.; Trau, M. Simple Isothermal Strategy for Multiplexed, Rapid, Sensitive, and Accurate miRNA Detection. ACS Sens. 2016, 1, 670-675. [CrossRef]

199. Dunnett, H.; van der Meer, D.; Williams, G.A. Evaluation of stem-loop reverse transcription and poly-A tail extension in microRNA analysis of body fluids. Microrna 2014, 3, 150-154. [CrossRef] [PubMed]

200. Abudayyeh, O.O.; Gootenberg, J.S.; Kellner, M.J.; Zhang, F. Nucleic Acid Detection of Plant Genes Using CRISPR-Cas13. CRISPR J. 2019, 2, 165-171. [CrossRef]

201. Addgene pC013-Twinstrep-SUMO-huLwCas13a (Plasmid \#90097). Available online: https://www.addgene.org/90097/ (accessed on 2 June 2021).

202. Ding, M.; Wang, C.; Lu, X.; Zhang, C.; Zhou, Z.; Chen, X.; Zhang, C.Y.; Zen, K.; Zhang, C. Comparison of commercial exosome isolation kits for circulating exosomal microRNA profiling. Anal. Bioanal. Chem. 2018, 410, 3805-3814. [CrossRef] 